\title{
OWIES W GRECKICH TRAKTATACH MEDYCZNYCH STAROŻYTNOŚCI I BIZANCJUM (V w. prz. Chr. - XI w. po Chr. $)^{1}$
}

Owies najczęściej nazywano po grecku $\beta \rho o ́ \mu \varsigma^{2}$, zapisując to określenie przez omikron. Niekiedy jednak używano także tego terminu z omegą $\beta \rho \hat{\omega} \mu \varsigma^{3}$ oraz formy $\beta o ́ p \mu o \varsigma^{4}$, a także, najprawdopodobniej dla mniej popular-

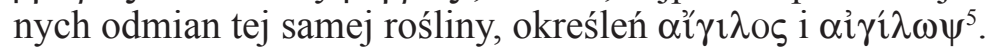

Co do starożytnej i bizantyńskiej klasyfikacji tego zboża, to spuścizna Galena (II/III w.) zawiera wszystkie istotne przyporządkowania, które pojawiały się również w późniejszej literaturze medycznej. Lekarz ten zaliczał

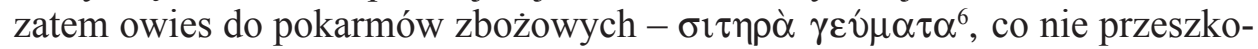

* Dr hab. Maciej Kokoszko, prof. UŁ - kierownik Katedry Historii Bizancjum w Instytucie Historii na Wydziale Filozoficzno-Historycznym Uniwersytetu Lódzkiego; e-mail: mkokoszko@komandor.pl.

${ }^{* *}$ Mgr Krzysztof Jagusiak - doktorant przy Katedrze Historii Bizancjum w Instytucie Historii na Wydziale Filozoficzno-Historycznym Uniwersytetu Łódzkiego; e-mail: krzysztof_jagusiak@o2.pl.

${ }^{* * *}$ Mgr Zofia Rzeźnicka - doktorantka przy Katedrze Historii Bizancjum w Instytucie Historii na Wydziale Filozoficzno-Historycznym Uniwersytetu Łódzkiego; e-mail: zosia_pwp.historyk@wp.pl.

${ }^{1}$ Artykuł został napisany w związku z grantem 2011/01/BHS3/01020. Obecne studium jest rozszerzeniem wyników badań zawartych w: M. Kokoszko, Smaki Konstantynopola, w: Konstantynopol - Nowy Rzym. Miasto i ludzie w okresie wczesnobizantyńskim, red. M.J. Leszka - T. Wolińska, Warszawa 2011, 480-482; M. Kokoszko - K. Jagusiak, Zboża Bizancjum. Kilka uwag na temat roli produktów zbożowych na podstawie źródeł greckich, „Zeszyty Wiejskie” 17 (2012) 31-33.

2 Alexander Trallianus, De febribus I 371, 9-10, ed. T. Puschmann: Alexander von Tralles, Original-Text und Übersetzung nebst einer einleitenden Abhandlung: Ein Beitrag zur Geschichte der Medicin, I, Vienna 1878 (reprint: Amsterdam 1963), 352-353.

${ }^{3}$ Na przykład - Alexander Trallianus, Therapeutica II 221, 15, ed. T. Puschmann: Alexander von Tralles: Original-Text und Übersetzung nebst einer einleitenden Abhandlung: Ein Beitrag zur Geschichte der Medicin, II, Vienna 1879 (reprint: Amsterdam 1963), 221.

${ }^{4}$ Oribasius, Collectiones medicae IV 7, 20, 1, ed. I. Raeder: Oribasii Collectionum medicarum re-

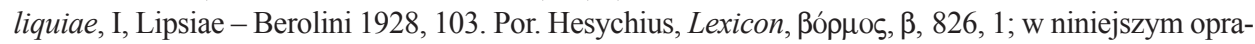
cowaniu posługiwano się wydaniem: M. Schmidt: Hesychii Alexandrini Lexicon, I-V, Ienae 1858-1868.

${ }^{5}$ Por. K.T. Witczak, Indoeuropejskie nazwy zbóż, Łódź 2004, 66-71.

${ }^{6}$ Galenus, In Hippocratis de victu acutorum commentaria IV 454, 10-11, ed. G. Helmreich: Galeni In Hippocratis de victu acutorum commentaria, Lipsiae 1914, 134. 
dziło mu wszakże przy innej okazji włączyć go do kategorii ő $\sigma \pi \rho \alpha^{7}$, czyli nominalnie do grupy roślin strączkowych ${ }^{8}$.

Podczas gdy pierwsze przyporządkowanie nie budzi zastrzeżeń z punktu widzenia współczesnej wiedzy, to kolejne wydaje się dość zaskakujące. Niemniej, owa kategoryzacja nie mogła budzić sprzeciwu w czasach antyku i Bizancjum, ponieważ dzięki autorytetowi Galena zyskała popularność, na co wskazuje choćby dorobek Orybazjusza (IV w. po Chr.) $)^{9}$ czy Aleksandra z Tralles ${ }^{10}$. Wydaje nam się jednak, że stanie się ona znacznie bardziej zrozumiała, gdy dopuścimy hipotezę, iż termin ö $\sigma \pi \rho \iota \alpha$ był pojmowany przez znawców dietetyki znacznie szerzej, niż jest to czynione obecnie. Dowodem na słuszność takiego właśnie rozumowania jest fakt, iż omawiane pojęcie obejmowało, na przykład, także ryż. Stosownie zatem do zawartości pism medycznych, a zwłaszcza zgodnie z Galenowymi rozważaniami na temat tego ostatniego zboża, przyjmiemy, że termin ő $\sigma \pi \rho \imath \alpha$ oznaczał nie tylko rośliny strączkowe, ale też i nasiona wszelkich innych upraw, które, stanowiąc bazę pokarmową ówczesnego społeczeństwa, nie nadawały się w normalnych okolicznościach do wypieku chleba ${ }^{11}$. Taka definicja zapewne lepiej odpowiada rozumieniu tego pojęcia przez dietetyków.

1. Owies w świecie śródziemnomorskim i północnych prowincjach państwa rzymskiego. Owies (Avena L.) jest rośliną należącą do jednorocznych traw z rodziny wiechlinowatych (Poaceae Barnh., dawniej Gramineae Juss.). Spośród około trzydziestu gatunków, na jakie się dzieli ${ }^{12}$, najważniejszą rolę $\mathrm{w}$ dzisiejszej gospodarce odgrywa owies zwyczajny (Avena sativa L.). Innymi gatunkami uprawnymi, stosowanymi obok niego na przestrzeni dziejów w żywieniu człowieka były: owies bizantyński lub czerwony (Avena byzantina $\mathrm{C}$. Koch.), owies abisyński (Avena abyssynica Hochst.), owies nagoziarnkowy zwany również nagim (Avena nuda L.) i owies szorstki zwany też owsikiem (Avena strigosa Schreb.) ${ }^{13}$. Należy przy tym zaznaczyć, że na

${ }^{7}$ Tenże, De simplicium medicamentorum temperamentis ac facultatibus libri XI 855, 1-2, ed. D.C.G. Kühn, Claudii Galeni Opera omnia, XI, Lipsiae 1826, 855.

${ }^{8}$ Por. Liddell - Scott, s. 1262 , s.v. ő $\sigma \pi p t o v$.

${ }^{9}$ Por. Oribasius, Collectiones medicae IV 7, 20, 1.

${ }^{10}$ Por. Alexander Trallianus, Therapeutica II 221, 13-15.

${ }^{11}$ Por. Galenus, De alimentorum facultatibus lib. 524, 11-16; w niniejszym opracowaniu posługiwano się wydaniem: G. Helmreich, Galeni De sanitate tuenda libri VI, De alimentorum facultatibus libri III, De bonis malisque sucis liber, De victu attenuante liber, De ptisana liber, Lipsiae - Berolini 1923, 199-386.

${ }^{12}$ Liczba gatunków owsa szacowana jest na nie mniej niż trzydzieści, por. M. Grynia, Owies, w: Trawy uprawne i dziko rosnace, red. M. Falkowski, Warszawa 1974, 135; D.M. Peterson J.P. Murphy, Oat, w: The Cambridge World History of Food, ed. K.F. Kiple - K. Coneè Ornelas, Cambridge 2000, 121; E. Paczos-Grzęda, Systematyka, ewolucja i cytogenetyka gatunków z rodzaju Avena L., „Wiadomości Botaniczne” 47 (2003) nr 1-2, 7; J.F. Hancock, Plant evolution and the origin of crop species, Wallingford - Cambridge Mass. 2004, 183.

${ }^{13}$ Por. Grynia, Owies, s. 136-139; I.G. Loskutov, On Evolutionary Pathways of „,Avena” spe- 
interesujących nas przede wszystkim obszarach, to znaczy na terenach okalających Morze Śródziemne, a także na przestrzeniach sąsiadujących z nimi od północy krain europejskich znano i stosowano owies zwyczajny i bizantyński (z przewagą tego ostatniego) ${ }^{14}$.

$\mathrm{Na}$ tle historii upraw większości spośród pozostałych roślin zbożowych, dzieje kultywacji owsa zajmują miejsce szczególne i nietypowe ${ }^{15}$. Otóż gdy ponad 10 tys. lat przed Chr. mieszkańcy Bliskiego Wschodu zaczęli z powodzeniem stosować w swej diecie pszenicę i jęczmień, stopniowo udomawiając oba te rodzaje i obsiewając nimi swe pola, zakradały się tam również liczne odmiany niepożądanych chwastów. Twardo rywalizując z faworyzowanymi przez rolników roślinami, zmniejszały one ich plony i dlatego były, w dużej mierze bezskutecznie, tępione. Wśród owych agresywnych intruzów znalazły się również nasiona dzikich odmian owsa.

Dane świadczące o takiej początkowej roli mawianego zboża obecne są w wielu źródłach literackich pochodzących z okresu starożytności, a informacje odnoszące się do tej samej kwestii nieobce są także traktatom bizantyńskim, co w sumie pozwala domyślić się, iż w całym okresie, który pozostaje w centrum zainteresowania naszych rozważań, owies odgrywał zawsze i niezmiennie rolę podwójną, a mianowicie rośliny uprawnej oraz chwastu ${ }^{16}$. Wystarczy kilka zaczerpniętych ze źródeł informacji, by zilustrować to zjawisko. I tak w I w. po Chr. Pliniusz utrzymywał, że jęczmień jest często zachwaszczany przez owies (i inne analogicznie do niego wyglądające rośliny) oraz że choroby jęczmienia biorą się z sąsiedztwa owego niechcianego zboża ${ }^{17}$. Nadto piszący w VI w. Hezychiusz pozostawił informację, że choć za jego czasów owies wysiewany był celowo w wielu miejscach basenu Morza Śródziemnego, to także w licznych rósł po prostu dziko ${ }^{18}$. Trzeba dodać, że jeszcze w opublikowanych w X w. Geoponika omawiane przez nas zboże opisywane było jako roślina, która często zagrażała bardziej poży-

cies, „Genetic Resources and Crop Evolution” 55 (2008) 211-220. Zob. także Z. Celka, Relikty dawnych upraw - jak rośliny pomagają w badaniach archeologicznych, w: Człowiek i środowisko przyrodnicze we wczesnym średniowieczu w świetle badań interdyscyplinarnych, red. W. Chudziak, Torun 2008, 112.

${ }^{14}$ Por. J. Mowszowicz, Z dziejów roślin uprawnych, cz. 1: Zboża, Warszawa 1948, 52; M. Nowiński, Dzieje upraw i roślin uprawnych, Poznań 1957, 66; Szczegółowa uprawa roślin, cz. 1, red. A. Listowski, Warszawa 1966, 212. Zob. także A.G. Górny, Zarys genetyki owsa (rodzaj „Avena” L.), w: Zarys genetyki zbóż, II, red. A.G. Górny, Poznań 2005, 314-319.

${ }^{15}$ Opisaną poniżej historię udomowienia owsa można porównać jedynie z podobnym procesem, jaki dotyczył żyta. Por. H. Küster, Rye, w: The Cambridge World History, s. 149-150; Hancock, Plant evolution, s. 188.

${ }^{16}$ Por. A. Hyland, Equus: the horse in the Roman world, New Haven - London 1990, 40: „Oats were considered a type of degenerate barley [...]".

${ }^{17}$ Por. Plinius, Historia naturalis XVIII 44, 149-150; w niniejszym opracowaniu posługiwano się wydaniem: Pliny, Natural History, with an English Translation in Ten Volumes, transl. H. Rackham, London - Cambridge Mass. 1938-1963.

${ }^{18}$ Por. Hesychius, Lexicon, ßóp $\mu$ os, $\beta$, 826, 1-2. 
tecznym zasiewom (w tekście ponownie pojawia się jęczmień jako uprawa najbardziej dotknięta tym niebezpieczeństwem). Chociaż dowiadujemy się tego $\mathrm{z}$ fragmentu księgi II, który stanowi wypis z dzieła napisanego w I w. przed Chr. przez Paksamosa ${ }^{19}$, to jednak sam fakt włączenia powyższych informacji przez autora Geoponika do jego pracy, pozwala domyślać się, iż Paksamosowe refleksje miały ciągle jeszcze swoje zastosowanie w warunkach Bizancjum, a zatem, że opisywane zjawisko było znane przynajmniej aż do X w., to znaczy do czasów powstawania Geoponika.

Interesująca nas trawa wykazywała się dużymi zdolnościami przystosowawczymi $\mathrm{i}$, co bardzo istotne, była w stanie przetrwać również na obszarach charakteryzujących się chłodniejszym klimatem ${ }^{20}$, jak środkowa i północna Europa $^{21}$, gdzie pszenica i jęczmień, wrażliwsze na niższe temperatury i wymagające lepszych jakościowo gleb, udawały się starożytnym dużo gorzej22. $Z$ tego też względu ludy zamieszkujące na północ od Dunaju i Alp uprawiały i spożywały owies w znacznie większym stopniu niż przedstawiciele interesujących nas przede wszystkim społeczeństw śródziemnomorskich ${ }^{23}$, a nadto traktowały go jako ważny składnik swej diety, choć dla nich również nie sta-

${ }^{19}$ Por. Cassianus Bassus, Geoponica II 43; w niniejszym opracowaniu posługiwano się wydaniem: Geoponica sive Cassiani Bassi Scholastici de re rustica eclogae, recensuit H. Beckh, Lipsiae 1895. Paksamos żył zapewne w I w. przed Chr. Napisał traktat o rolnictwie Georgika w przynajmniej trzech księgach, dzieło o pokarmach Opsartytika, opusculum o sztuce farbiarskiej Baphika, dziełko na temat historii Beocji Boiotika oraz rozprawę, która nosiła tytuł Dodekatechnon, por.

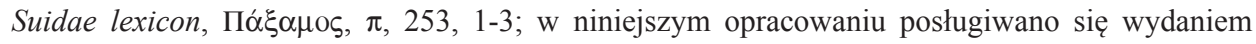
A. Adler, I-IV, Lipsiae 1928-1935.

${ }^{20}$ Należy przy tym jasno zaznaczyć, że pomimo swej zwiększonej odporności na chłód, owies, tak jak pszenica i jęczmień, nie znosił dobrze przymrozków. Jeżeli dodamy do tego fakt, iż w swym cyklu wegetacji potrzebował więcej wody niż jęczmień, znajdziemy wytłumaczenie, dlaczego na południu Europy nie mógł on z tym drugim zbożem skutecznie konkurować o względy człowieka. Znacznie jednak lepiej niż pszenica i jęczmień rósł na gorszym podłożu. Na temat wymagań klimatycznych i glebowych owsa zob. K.R. Majors, Cereal Grains as Food and Feed, w: Crops in Peace and War. The Yearbook of Agriculture 1950-1951, ed. A. Stefferud, Washington D.C. 1952, 5; Szczegótowa uprawa roślin, s. 213, 218; S. Lewicki - J. Mazurek, Owies, Warszawa 1967, 4.

${ }^{21} \mathrm{~W}$ niniejszym artykule pomijamy rozprzestrzenianie się owsa na Środkowy i Daleki Wschód, a także na południe, w stronę górnego biegu Nilu. Na temat tych dróg zob. krótką wzmiankę D.M. Petersona i J.P. Murphy'ego (Oat, s. 122).

${ }^{22}$ Por. M. Lityńska-Zając - K. Wasylikowa, Przewodnik do badań archeobotanicznych, Poznań 2005, 104; M. Lityńska-Zając, Chwasty w uprawach roślinnych w pradziejach $i$ wczesnym średniowieczu, Kraków 2005, 42-43.

${ }^{23}$ Por. D. Brothwell - P. Brothwell, Food in Antiquity. A Survey of the Diet of Early Peoples, London 1969, 100-101; M. Lityńska-Zając, Roślinność i gospodarka rolna w okresie rzymskim. Studium archeobotaniczne, Kraków 1997, 34; M. Rösch - S. Jacomet - S. Karg, The History of Cereals in the Region of the Former Dutchy of Swabia (Herzogtum Schwaben) from the Roman to the Post-Medieval Period: Results of Archaeobotanical Research, „Vegetation History and Archaeobotany" 1 (1992) 193-209 (dane obrazujące przemiany w roli owsa na obszarze południowych Niemiec i Szwajcarii); R. Grabowski, Changes in Cereal Cultivation During the Iron Age in Southern Sweden: A Compilation and Interpretation of the Archaeobotanical Material, ,Vegetation 
nowił on, przynajmniej aż do czasów średniowiecza, podstawowego zboża ${ }^{24}$. Ważne jest również to, że od połowy I w. przed Chr. w Galii, a później od lat 40-tych I w. po Chr. w Brytanii, gdy ziemie te zostały zdobyte i zamienione w rzymskie prowincje, stacjonowały stale tysiące żołnierzy pochodzących z południa Europy. Ludzie ci, zdani na wojskową kuchnię, która zaopatrywała się na miejscowych rynkach w lokalne produkty, karmieni byli czasem, między innymi, owsem, traktowanym przez tubylców jak codzienny, zwyczajny pokarm ${ }^{25}$. Nie dziwi zatem, że uprawa owsa na wymienionych obszarach poświadczona jest dobrze przez liczne rzymskie źródła literackie. Na przykład Pliniusz utrzymywał, iż zboże to spożywane było w Germaniii ${ }^{26}$, a ponieważ wymienia je też Antimus, trzeba przypuszczać, że w VI w. owies ciągle był znany ${ }^{27}$ wśród Franków, a w postaci pewnych dań podawano go nawet frankijskiej arystokracji.

W świecie śródziemnomorskim, pomimo tego, że stanowił roślinę rodzimą na tym obszarze, owies nie był wysoko cenioną uprawą. Rósł tu wprawdzie powszechnie, co zaświadcza choćby Katon dla Italii w II w. przed Chr. ${ }^{28}$ czy Galen $^{29}$ dla Azji Mniejszej przełomu I i II w., ale wypada domyślać się, że ciągle traktowano go jako w dużej mierze niepożądaną domieszkę do dominującego kultywara ${ }^{30}$. Nie mógł zatem konkurować z zaadaptowanymi wcześniej i lepiej do ludzkich potrzeb pszenicą, z której wyrabiano najczęściej pieczywo, oraz jęczmieniem, z którego powstawała przede wszystkim gęsta papka, określana przez Greków jako $\mu \hat{\alpha} \zeta \alpha$, albo rzadsza od $\mu \widehat{\alpha} \zeta \alpha$ zupa zwana $\pi$ ó $\lambda \tau$ os. Główną tego przyczyną był fakt, że te same produkty uzyskiwane z przetwo-

History and Archaeobotany" 20 (2011) 479-494 (dane dla obszaru południowej Szwecji w okresie od I do V w. po Chr.).

${ }^{24}$ Por. M. Montanari, Structures de production et systèmes alimentaires, w: Histoire de l'alimentation, ed. J.L. Flandrin - M. Montanari, Paris 1996, 288-289; Lityńska-Zając - Wasylikowa, Przewodnik do badań archeobotanicznych, s. 106. Nieco inaczej sytuacja wyglądała na Wyspach Brytyjskich, gdzie w dużo większym stopniu wykorzystywano owies w codziennej diecie jeszcze przed nastaniem średniowiecza. Zob. Peterson - Murphy, Oat, s. 128.

${ }^{25}$ Por. J.P. Alcock, Food in Roman Britain, Brimscombe Port 2001, 18; K. Britton - J. Huntley, New Evidence for the Consumption of Barley at Romano-British Military and Civilian Sites, from the Analysis of Cereal Bran Fragments in Faecal Material, „Vegetation History and Archaeobotany” 20 (2011) 49 (artykuł poświęcony wprawdzie przede wszystkim roli jęczmienia, jednak wykazujący również pozostałości owsa w rzymskich obozach legionowych, także tam, gdzie nie stacjonowały oddziały jazdy, które karmiłyby nim swe konie). Owies jako pasza dla koni także por. Hyland, Equus, s. 40.

${ }^{26}$ Por. Plinius, Historia naturalis XVIII 44, 149.

${ }^{27}$ Por. Anthimus, De observatione ciborum 64; w niniejszym opracowaniu posługiwano się wydaniem: M. Grant: Anthimus, On the Observance of Foods, Totnes - Blackawton - Devon 2007.

${ }^{28}$ Por. Cato Marcius Porcius, De agri cultura 37, 5; w niniejszym opracowaniu posługiwano się wydaniem: M. Porci Catonis De agri cultura liber, rec. H. Keil, Lipsiae 1895.

${ }^{29}$ Por. Galenus, De alimentorum facultatibus lib. 522, 15 - 523, 1.

${ }^{30}$ Por. Hancock, Plant evolution, s. 185. 
rzenia owsa ${ }^{31}$ były mniej pożądanym przez miejscowych konsumentów towarem, ocenianym jako charakteryzujący się gorszą jakością i smakiem ${ }^{32}$.

$\mathrm{Z}$ drugiej strony jednak nierzadko mieszkańcy omawianej części świata byli zmuszeni zaspokajać swój głód owsem. Działo się tak wówczas, gdy nieurodzaj zniszczył plony pszenicy i jęczmienia, wobec czego zbiory tych dwóch zbóż nie były w stanie sprostać zapotrzebowaniom miejscowej społeczności. Niedobory uzupełniano rozmaitymi roślinnymi surowcami zastępczymi, spośród których znakomicie nadawały się do tej roli te, które otrzymywano z owsa ${ }^{33}$. Odzwierciedleniem tego zjawiska są uwagi Galena ${ }^{34}$, które szkicują sytuację wschodniej części basenu Morza Śródziemnego na przełomie I i II w., a które potem powtórzone zostały w IV w. przez Orybazjusza ${ }^{35}$. Galen utrzymywał, że owies, choć rośnie w dużych ilościach w Myzji ${ }^{36}$, nie jest tam traktowany jako surowiec do wypiekania chleba, chyba że w sytuacji skrajnego głodu. Nie znaczy to, że poza okresami niedostatku nie był on w ogóle jadany. Wprost przeciwnie, wtedy przyrządzało się z niego coś

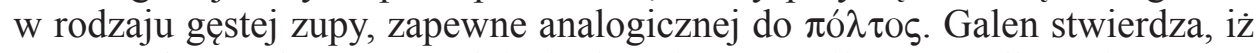
to pogardzane zboże normalnie i głównie stanowiło paszę dla zwierząt, co zresztą potwierdza zarówno piszący w I w. po Chr. Kolumella ${ }^{37}$ (twierdzący, że mieszano go w tym celu z jęczmieniem), jak i działający trzysta lat później Orybazjusz $^{38}$. Geoponika podpowiadają nam również, że ciągle jeszcze w X w. zwierzęta żywione były analogiczną paszą. Z fragmentu księgi XVIII, któ-

${ }^{31}$ Por. poniżej.

${ }^{32}$ Por. informacje Galena (De alimentorum facultatibus lib. 523, 7) na temat smaku chleba wypiekanego z owsa. Interpretujemy je jako ślady swego rodzaju kulturowo ugruntowanej niechęci. Zob. A. Dalby, Siren Feasts. A History of Food and Gastronomy in Greece, London - New York 1996, 90; J.P. Alcock, Food in the Ancient World, London 2006, 34. Naturalnie nie jesteśmy w stanie prześledzić indywidualnych zamiłowań kulinarnych ludzi omawianego okresu, wśród których mógł znaleźć się niejeden amator produktów uzyskiwanych z owsa. Przytłaczająca większość, mając wybór, sięgała jednak po inne zboża.

${ }^{33}$ Przyczyny sięgania w antycznej kuchni śródziemnomorskiej po owies podają: J.P. Alcock (Food in the Ancient World, s. 34) oraz J.M. Wilkins i S. Hill (Food in the Ancient World, Oxford 2006, 118-119).

${ }^{34}$ Por. Galenus, De alimentorum facultatibus lib. 522, 15 - 523, 4.

${ }^{35}$ Por. Oribasius, Collectiones medicae I 14, 1, 3 - 2, 1.

${ }^{36}$ Por. A. de Condolle, Origin of Cultivated Plants, New York 1959, 373-374: „The cultivation of oats was, therefore, practiced anciently to the north of Italy and of Greece. It was diffused later and partially in the south of the Roman empire. It is possible that it was more ancient in Asia Minor, for Galen says oats were abundant in Mysia, above Pergamus; that they were given to horses, and that men used them for food in years of scarcity".

${ }^{37}$ Por. Lucius Junius Moderatus Columella, Res rustica II 10, 24; w niniejszym opracowaniu posługiwano się wydaniem: On Agriculture, with a recensione on the Text and an English Translation by H. Boyd Ash (I), E.S. Forster - E.H. Heffner (II-III), I-III, London - Cambridge Mass. 1960-1979.

${ }^{38}$ Por. Oribasius, Collectiones medicae I 14, 1, 1. 
ry jest wyciągiem z prac piszącego w III w. Florentyna ${ }^{39}$, dowiadujemy się bowiem, iż zboże to stanowiło pokarm odpowiedni dla owiec ${ }^{40}$.

O ograniczonej roli owsa jako składnika menu ówczesnych mieszkańców Śródziemnomorza świadczy także fakt, iż niezbyt interesowała się nim medycyna starożytna. Jest to szczególnie symptomatyczne zjawisko, ponieważ sztuka ta była w znacznym stopniu skoncentrowana na sprawach diety pojmowanej jako środek terapeutyczny, a zatem traktaty medyczne zawierają zwykle szczególnie wiele detali na temat wykorzystania artykułów żywnościowych w różnorodnych procedurach medycznych. Warto zwrócić uwagę, że pomimo uwag w Corpus Hippocraticum ${ }^{41}$ i Dioskuridesa ${ }^{42}$, jakie odnajdujemy w ich zachowanej spuściźnie, brakuje wzmianek na temat właściwości, cech dietetycznych i sposobów przyrządzaniu owsa w podsumowaniu dorobku antyku na ten temat, a więc w drugowiecznych Deipnosofistach Atenajosa z Naukratis ${ }^{43}$. W zamian za to $\mathrm{w}$ dziele tym mamy informacje o rytualnym użyciu tego zboża. Autor ekscerpował bowiem fragment powstałego w II w. przed Chr. dzieła Polemona Periegety ${ }^{44}$, które opisuje tak zwany képvos, czyli naczynie ofiarne używane w uroczystościach ku czci Demeter i Kory (odbywających się w Eleusis $)^{45}$, oraz Kybele i Attysa ${ }^{46}$, a składające się ze znacznych rozmiarów pucharu na wysokiej nodze, do którego brzegu przymocowane były mniejsze

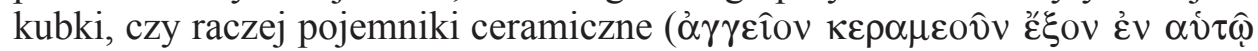

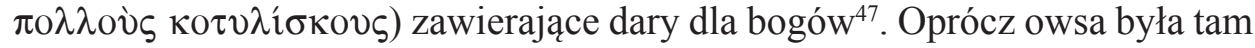
w czasach Polemona wkładana szałwia, biały mak, pszenica, jęczmień i wiele innych, dobrze znanych ówczesnym Grekom produktów, przede wszystkim

${ }^{39}$ Florentyn żył prawdopodobnie w III w. po Chr. i był autorem rozpraw na tematy rolnicze określanych jako Georgika w co najmniej XI księgach [por. E. Oder, Beiträge zur Geschichte der Landwirtschaft bei den Griechen, I, „Rheinisches Museum” 45 (1890) 87]. Wymieniany przez Focjusza (Bibliotheca cod. 163 i 107).

${ }^{40}$ Por. Cassianus Bassus, Geoponica XVIII 2, 6.

${ }^{41}$ Por. niżej.

${ }^{42}$ Por. niżej.

${ }^{43} \mathrm{Na}$ temat powiązań Deipnosofistów z dorobkiem medycyny antycznej zob. J.N. Corvisier, Athenaeus, Medicine and Demography, w: Athenaeus and His World. Reading Greek Culture in the Roman Empire, ed. D. Braund - J. Wilkins, Exeter 2000, 492-502; R. Flemming, The Physicians at the Feats. The Place of the Medical Knowledge at Athenaeus' Dinner-table, w: Athenaeus and His World, s. 476-482. Dzieło Atenajosa należy także uznać za pełne szczegółowych wzmianek na temat dietetyki antycznej por. M. Kokoszko, Aromaty kuchni antyku oraz wczesnego Bizancjum w teorii medycznej i praktyce kulinarnej, PHis 102 (2012) z. 4, 537.

${ }^{44}$ Por. Athenaeus Naucratita, Deipnosophistae 478d (56, 17-26); w niniejszym opracowaniu posługiwano się wydaniem: Athenaei Naucratitae Dipnosophistarum libri XV, recensuit G. Kaibel, I-III, Lipsiae 1887-1890.

${ }^{45}$ Por. G.E. Mylonas, Eleusis and the Eleusinian Mysteres, Princeton 1962, 221-222, tablica 87.

${ }^{46}$ Por. A. Bignasca, Kernos, w: Thesaurus Cultus and Rituum Antiquorum, V, ed. J.Ch. Balty, Basel - Los Angeles 2005, 250-252.

${ }^{47}$ Por. J. Collins-Clinton, A late Antique Shrine of Liber Pater at Cosa, Leiden 1976, 30. 
pokarmów, choć nie tylko ${ }^{48}$. Naczynie owo używane było w czasie kernoforii

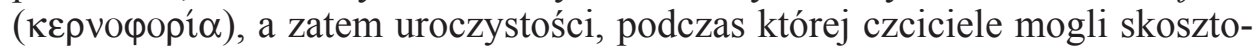
wać darów bogin. Choć na pierwszy rzut oka informacje te zdają się wskazywać na rozpowszechnienie użycia omawianego zboża przynajmniej w starożytności, naszym zdaniem interpretacja taka byłaby przynajmniej nieprecyzyjna. Wydaje nam się bowiem wielce symptomatyczne, że Ammonios ${ }^{49}$, inny autor, który opisywał ten sam sprzęt liturgiczny, nie wzmiankował już owsa jako zawartości poszczególnych kotyliskoi. Owies zatem nigdy nie stanowił opcji podstawowej w rytuale opisanym powyżej.

Przez kolejne stulecia kulinarne upodobania Greków, Rzymian i innych ludów żyjących w strefie śródziemnomorskiej nie zmieniły się na tyle, by omawiane przez nas zboże stało się powszechnie składnikiem codziennych posiłków. Wciąż jednak chłopi obsiewali nim część swoich gruntów, traktując je głównie jako roślinę pastewną i pokarm zastępczy w okresie głodu ${ }^{50}$. Sytuacja powyższa utrzymała się bez większych zmian aż do końca interesującego nas okresu również w okresie Cesarstwa Bizantyńskiego ${ }^{51}$, gdzie wzrost produkcji owsa nastąpił dopiero od XI/XII w., wraz z wieloma innymi zaistniałymi wówczas przemianami w tamtejszym rolnictwie. Jednak nawet wówczas Bizantyńczycy nie docenili w pełni walorów owsa ${ }^{52}$. Dowodzą tego cytowane w niniejszym studium oceny omawianego zboża skomponowane przez Symeona Setha ${ }^{53}$. Nic nie wskazuje również na to, by zaistniała pod rządami muzułmańskimi tzw. arabska rewolucja rolnicza przyniosła jakąkolwiek poprawę postrzegania omawianego zboża i wzrost jego spożycia przez zamieszkującą interesujące nas obszary ludność, która znalazła się pod panowaniem najeźdźców.

2. Właściwości dietetyczne. Chociaż trudno nazwać owies popularnym i cenionym produktem żywnościowym, to jednak nauka antyku i Bizancjum wypracowała dość spójny zbiór poglądów, który można nazwać charaktery-

${ }^{48}$ Była tam także wełna (๕̌prov).

${ }^{49}$ Por. Athenaeus Naucratita, Deipnosophistae XI $476 \mathrm{f}$ (52, 1-6, Kaibel).

${ }^{50}$ Por. A. Dalby, Flavours of Byzantium, Totnes 2003, 77-78; tenże, Tastes of Byzantium. The Cuisine of a Legendary Empire, Lndon - New York 2010, 77-78; M.L. Rautman, The Daily Life in the Byzantine Empire, Westport - Oxford 2006, 173 i 177.

${ }^{51}$ Por. J.L. Teall, The Grain Supply of the Byzantine Empire, 330-1025, DOP 13 (1959) 99; J. Lefort, The Rural Economy, Seventh-Twelfth Centuries, w: The Economic History of Byzantium. From the Seventh Through the Fifteenth Century, ed. A.E. Laiou, Washington DC 2002, 251.

52 Por. A.E. Laiou, The Byzantine Economy. An Overview, w: The Economic History of Byzantium, s. 1150-1151. Warto w tym miejscu zwrócić uwagę na nieco ironicznie brzmiącą (w kontekście deprecjonowania przez Greków zarówno w okresie antyku jak i Bizancjum) nazwę omawianego zboża, stosowaną współcześnie na określenie odmiany właściwej dla obszarów śródziemnomorskich, mianowicie na określenie owies bizantyński (Avena bizantina). Z pozoru bowiem mogłoby ono sugerować szczególne zamiłowanie mieszkańców cesarstwa do owej rośliny.

${ }^{53}$ Por. niżej. 
styką dietetyczną tego pokarmu. Nie powinno nas to zresztą dziwić, ponieważ medycy greccy opisywali w analogiczny sposób wszystkie znane im produkty żywnościowe.

Z dostępnych danych wypada wnioskować, iż owies musiał być względnie znanym pokarmem w czasach Hipokratesa i jego bezpośrednich następców, gdyż ci poświęcili mu nieco uwagi. Choć charakterystyka tego zboża była krótka ${ }^{54}$, zawierała jednak ustalenia, które powtarzane były przez Hipokratesowych uczniów w ciągu następnych stuleci. Mianowicie, w De diaeta odnajdujemy stwierdzenie, że owies nawilża i ochładza, zarówno gdy jest jedzony ( $\check{\varepsilon} \sigma \theta \imath o ́ \mu \varepsilon v o \varsigma)$, jak i przygotowany w formie nadającej się do picia ( szkołę hipokratejską jako immanentna cecha charakteryzująca owies, która notabene powtarzać się będzie w opisach właściwości tego zboża sporządzonych w wiele set lat po napisaniu De diaeta. Nawilżanie z kolei, jak wypada sądzić, było skutkiem metody przygotowywania owsa jako potrawy, a znaczy to, że autor De diaeta wskazywał tym samym, iż typowym sposobem jego podawania nie było wykorzystanie go w wypiekach, ale raczej przyrządzanie $\mathrm{z}$ niego gęstych papek i zup, gotowanych na wodzie, a analogicznych do

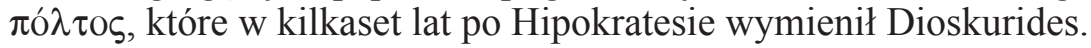

Ten ostatni, sporządzając opis owsa, zaczął swe uwagi od naszkicowania jego wyglądu. Pisał, że jest to rodzaj trawy podobny do pszenicy ( $\pi v \rho o \hat{\iota} \varsigma$ ö $\mu$ olos $)^{56}$. Jego łodyga poprzedzielana jest kolankami, gdy kłos pełen ziarna składa się z dwu części ${ }^{57}$. Sam właściwy opis cech dietetycznych owsa jest w dziełach Dioskuriedsa szczątkowy. Czytamy zatem jedynie, że zboże to doprowadza do spowolnienia, a nawet zatrzymania pracy przewodu pokarmowego $(\sigma \tau \alpha \lambda \tau \iota \kappa o ̀ \varsigma ~ \kappa o \imath \lambda i ́ \alpha \varsigma)^{58}$. Natomiast z zamieszczonej przez tego autora uwagi o zastosowaniu owsa w kataplazmach domyślać się wypada, że uważano, iż posiada on (przynajmniej miejscowo) właściwości rozgrzewające, umożliwiające diaforezę, a więc wydalanie produktów przemiany materii przez skórę ${ }^{59}$.

W porównaniu ze wspomnianym wyżej autorem De materia medica znacznie więcej danych na temat cech dietetycznych owsa dostarczył swym czytelnikom Galen. W De victu attenuante twierdził, że pozbawione osłonek i oczyszczone

\footnotetext{
${ }^{54} \mathrm{Na}$ temat autorstwa poszczególnych części Corpus Hippocraticum zob. V. Nutton, Ancient medicine, London - New York 2007, 60-62.

${ }^{55}$ Hippocrates, De diaeta 43, 2-3; w niniejszym opracowaniu posługiwano się wydaniem: Hippocratis De diaeta, edidit, in linguam francogallicam vertit, comentatus est R. Joly, adiuvante S. Byl, Berlin 2003.

${ }^{56}$ Pod względem kształtu jej liści.

${ }^{57}$ Por. Dioscurides Pedanius, De materia medica II 94, 1, 1-4; w niniejszym opracowaniu posługiwano się wydaniem: Pedanii Dioscuridis Anazarbei De materia medica libri quinque, ed. M. Wellmann, I-III, Berolini 1906-1914.

${ }^{58}$ Będąc precyzyjnym, należy stwierdzić, że cecha ta przypisana jest $\pi$ ó $\lambda$ 七o z owsa, por. Dioscurides Pedanius, De materia medica II 94, 1, 4-5.

${ }^{59}$ Por. Dioscurides Pedanius, De materia medica II 94, 1, 3-4.
} 
nasiona tego zboża mają działanie silniejsze ${ }^{60}$ niż pszenica, jęczmień i pszenica płaskurka (olyra $)^{61}$. W De alimentorum facultatibus z kolei, dodając znacznie więcej szczegółów na temat popularności i zastosowań owsa (o czym była już mowa powyżej), ograniczył charakterystykę dietetycznych cech omawianego zboża do stwierdzenia, iż jest ono rozgrzewające. Tę cechę, jak się dowiadujemy, dzieli z pszenicą samopszą, ale w nim występuje ona w stopniu niższym niż w tym ostatnim zbożu ${ }^{62}$. Nadto stwierdza, iż chleb upieczony z owsa nie jest smaczny ani pożywny, i nie oddziałuje na przewód pokarmowy ze zbyt wielka siłą, pozostając pożywieniem pośrednim, to znaczy ani nazbyt spowalniającym pracę jelit ani też nadmiernie je stymulującym ${ }^{63}$. W końcu w De simplicium alimentorum temperamentis ac facultatibus mowa jest wprost o jeszcze jednej cesze przypisywanej owsu, mianowicie o jego działaniu ściągającym ${ }^{64}$.

Doktryny zachowane w dziełach kolejnego wybitnego medyka, to znaczy Orybazjusza, a odnoszące się do omawianej kwestii, są zależne przede wszystkim od ustaleń Galena i Dieuchesa ${ }^{65}$ (ten drugi poprzedzał Orybazjusza o kilka wieków, gdyż działał w III w. przed Chr.). W dziełach Orybazjusza znajdujemy usystematyzowaną charakterystykę owsa i produktów z niego uzyskiwanych. Stała się ona integralną częścią III księgi Collectiones medicae i została potem powtórzona w Synopsis ad Eustathium filium oraz w Libri ad Eunapium. Z lektury wynika, że zarówno owies, jak i chleb z niego wypiekany, nie należały do produktów o cenionym aromacie ${ }^{66}$. Dlatego też wymienione

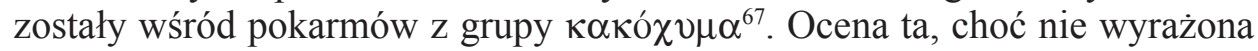
tymi samymi słowami, była zawarta także w Galenowym De alimentorum facultatibus, gdzie mowa była o złym smaku przypisywanym chlebowi z owsa. Ów nieprzyjemny aromat, czyli ợ $\delta i ́ \alpha, z$ pewnością był skutkiem i przejawem tej samej cechy pokarmowej, którą Orybazjusz określił jako к $\alpha \kappa o \chi v \mu i \alpha^{68}$. Klasyfikacja ta zresztą, co zapewne podkreśla jej normatywność, powtórzona została w Synopsis ad Eustathium filium ${ }^{69}$ oraz w Libri ad Eunapium ${ }^{70}$.

\footnotetext{
${ }^{60}$ Zapewne chodzi o wpływ na procesy trawienne.

${ }^{61}$ Por. Galenus, De victu attenuante 43, 2-3; w niniejszym opracowaniu posługiwano się wydaniem: Galeni De victu attenuante, ed. C. Kalbfleisch, Lipsiae 1923.

${ }^{62}$ Por. Galenus, De alimentorum facultatibus lib. 523, 3-6.

${ }^{63}$ Por. tamże 523, 6-8.

${ }^{64}$ Por. tenże, De simplicium medicamentorum temperamentis ac facultatibus 855, 6 .

${ }^{65}$ Autor m.in. dzieła poświęconego dietetyce, zachowanego tylko we fragmentach u innych autorów. Por. M. Wellmann, Dieuches (3), RE V 480. Fragmenty jego dzieł odtworzone zostały przez Janine Bertier (Mnésithée et Dieuches, Leiden 1972, 226-260). Krótki komentarz na temat charakteru jego twórczości por. tamże, s. 26-29.

${ }^{66}$ Por. Oribasius, Collectiones medicae III 16, 8, 1-2.

${ }^{67}$ Por. tamże III 16, 1, $1-18,3$.

${ }^{68}$ Zależność obu pojęć por. tamże I 1, 1, 1 - 15, 8, zwłaszcza I 1, 4, 5 - 5, 1 .

${ }^{69}$ Por. Oribasius, Synopsis ad Eustathium filium IV 15, 8, 1; w niniejszym opracowaniu posługiwano się wydaniem: Oribasii Synopsis ad Eustathium. Libri ad Eunapium, ed. I. Raeder, Lipsiae - Berolini 1926 (reprint Amsterdam 1964), 1-313.

${ }^{70}$ Por. tenże, Libri ad Eunapium I 33, 5, 2; w niniejszym opracowaniu posługiwano się wyda-
} 
Ponieważ zarówno samo zboże jak i wypieki z niego były oceniane przez niego jako trudne do wstępnego strawienia w żołądku ${ }^{71}$, Orybazjusz włączył oba produkty spożywcze do listy pokarmów z grupy $\delta$ $\sigma \pi \varepsilon \pi \tau \alpha^{72}$. I tym razem cecha ta wymieniona została zarówno w poradach dla syna ${ }^{73}$ jak i dla Eunapiusza ${ }^{74}$. Trzeba jednak pamiętać, że Orybazjusz znał też opinię Dieuchesa, który uważał owies za bardzo łatwy do przetworzenia we wstępnej fazie procesów trawiennych ${ }^{75}$.

Poza przytoczonymi dotąd danymi, w dziełach Orybazjusza możemy znaleźć również informacje mówiące o tym, że owies ma działanie wysuszające (bez uszkadzania tkanek - $\dot{\alpha} \delta \dot{\eta} \kappa \tau \omega \varsigma)^{76}$, czego dowiadujemy się w odpowied-

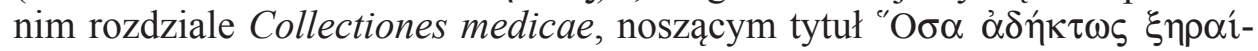
$v \varepsilon^{77}$, dalej w Synopsis ad Eustathium filium ${ }^{78}$ (we fragmencie po tym samym tytułem $^{79}$ ) i w końcu w Libri ad Eunapium ${ }^{80}$ (znowu w analogiczne zatytułowanym rozdziale ${ }^{81}$ ).

Owies został także zaliczony do pokarmów rozgrzewających ${ }^{82}$, o czym

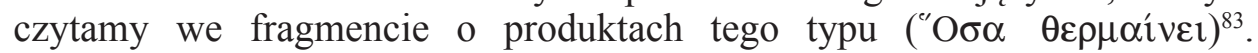
Ponownie te same refleksje znajdujemy w radach dla Eustacjusza ${ }^{84}$ i księgach dla Eunapiusza ${ }^{85}$. Dziwne jest jednak, że owies występuje także w zestawie pokarmów o właściwościach oziębiających. Czytamy o tym w odpowiednim

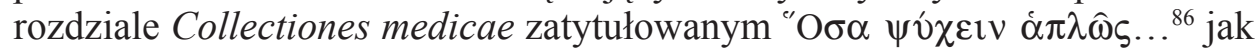

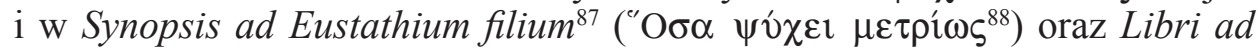

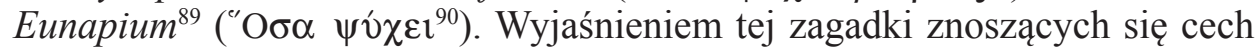
może być fakt, że właściwości chłodzące były jedynie nieznaczne i zapewne

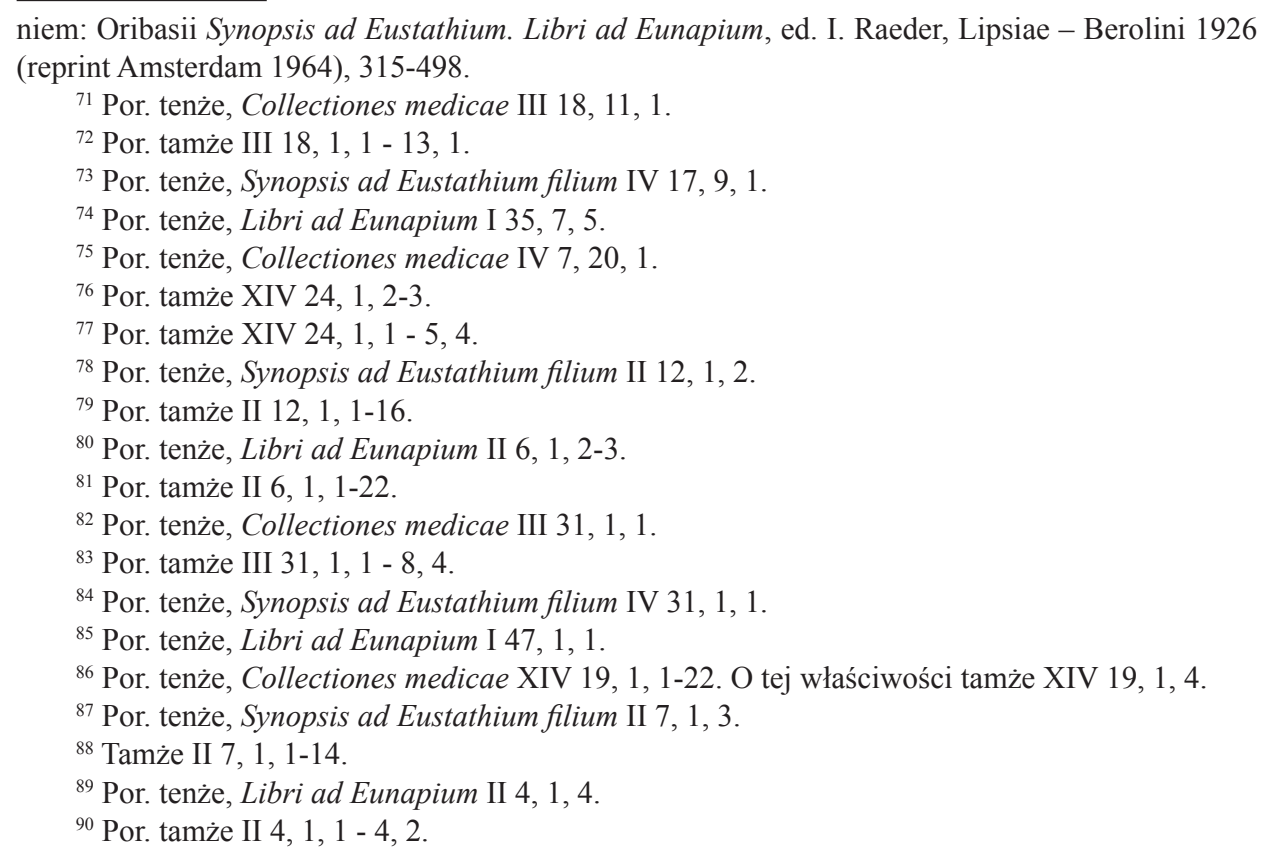


nadawały się do wykorzystania w jakichś dokładnie sprecyzowanych warunkach, które nie zostały jednak przekazane w rzeczonych dziełach.

Tworzący w VI w. Aecjusz z Amidy włączył do swego dzieła zatytułowanego Iatricorum libri stosunkowo krótką charakterystykę owsa, której miejscem jest księga I jego rozważań. Opisywał on tam substancje proste ( $\dot{\alpha} \pi \lambda \hat{\alpha}$ фó $\rho \mu \alpha \kappa \alpha)$. Czytamy, że owies jest w swej naturze chłodniejszy ${ }^{91}$ i nieco ściągający. Ta druga jego właściwość pozwala na zastosowanie go jako lekarstwa w leczeniu biegunek ${ }^{92}$.

Kolejne właściwości omawianego zboża odnajdziemy w tych rozdziałach księgi II, które (Orybazjuszowym wzorem) grupują produkty o konkretnych cechach dietetycznych. Ponieważ owies jest trudny do strawienia ${ }^{93}$, znajduje się w rozdziale o pokarmach charakteryzujących się tą samą cechą ${ }^{94}$. Jak w Collectiones medicae, również i tu lokalizujemy interesujące nas zboże ${ }^{95}$ w spisie pokarmów nie mających dobrych soków ${ }^{96}$. Nadto z Iatricorum libri, a dokładniej z rozdziału księgi II zatytułowanego "O $\sigma \alpha$ ỏ $\lambda \iota \gamma o ́ \tau \rho \circ \varphi \alpha^{97}$, dowiadujemy się także, że owies nie dostarcza wiele pokarmu ${ }^{98}$. Aecjusz z Amidy umieścił opisywane zboże również w spisie substancji ${ }^{99}$, które wysuszają, ale nie uszkadzają przy tym tkanek ${ }^{100}$. W końcu dowiadujemy się, że zboże ma właściwości oziębiające ${ }^{101}$ i jednocześnie odznacza się zdolnością do rozgrzewania ${ }^{102}$. W sumie zatem zakres informacji przekazany przez Aecjusza z Amidy jest analogiczny do tego, który zapisał w swych dziełach jego pergamoński poprzednik.

Piszący także w VI w. Aleksander z Tralles, w przeciwieństwie do Aecjusza z Amidy, nie rozwodził się wiele nad właściwościami owsa. W jego pismach znajdujemy jedynie informacje o sporządzaniu $\mathrm{z}$ tego zboża rzadkiej zupy czy też kleiku. Ponieważ danie to podawano osobom cierpiącym na gorączkę trzydniową, wypada wnioskować, że wykorzystywało ono zdolność wywaru $\mathrm{z}$ owsa do ochładzania organizmu ${ }^{103}$.

${ }^{91}$ Chodzi o to, że posiada tę cechę w większym stopniu niż poprzednio wymieniony produkt

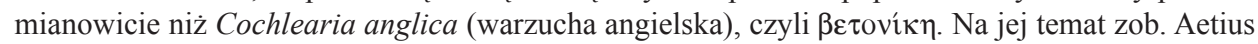
Amidinus, Iatricorum lib. I 72, 1-5; w niniejszym opracowaniu posługiwano się wydaniem: Aetii Amideni Libri medicinales I-VIII, ed. A. Olivieri, I-II, Lipsiae - Berolini 1935-1950.

${ }^{92}$ Por. Aetius Amidinus, Iatricorum lib. I 73, 1-2.

${ }^{93}$ Por. tamże II $255,18$.

${ }^{94}$ Por. tamże II 255, 1-25.

${ }^{95}$ Por. tamże II 253, 13.

${ }^{96}$ Por. tamże II 253, 1-37.

${ }^{97}$ Por. tamże II 251, 1-25.

${ }^{98}$ Por. tamże.

${ }^{99}$ Por. tamże II 208, 1-15.

${ }^{100}$ Por. tamże II 208, 2.

${ }^{101}$ Por. tamże II 203, 3.

102 Por. tamże II 267, 1.

${ }^{103}$ Por. Alexander Trallianus, De febribus I 371, 9-10. 
W VII w. Paweł z Eginy utrzymywał w księdze VII swej Epitome $e^{104}$, że owies posiada właściwości podobne do jęczmienia. Wysusza umiarkowanie i doprowadza do wydalenia produktów przemiany materii bez uszkadzania tkanek. Ma też działanie ściągające i dlatego używany jest jako środek przy leczeniu biegunek.

Stałość ustaleń widoczna jest także w źródłach, które powstały później niż w VII w. Tak jest na przykład w przypadku anonimowego traktatu datowanego

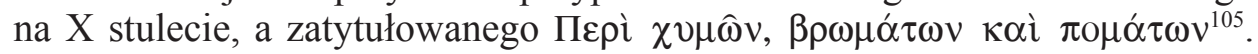
Zakres zamieszczonych w nim danych reprezentuje tradycję Orybazjusza, co widać $\mathrm{z}$ układu samego dzieła. $\mathrm{W}$ rozdziale dotyczącym pokarmów, które nie

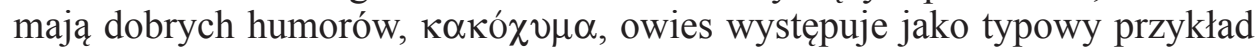
takiego działania niektórych produktów żywnościowych ${ }^{106}$. Nadto dowiadujemy się, że owies oceniony jest także jako niedostarczający organizmowi wiele pokarmu, a więc należący do ỏ $\lambda \imath \gamma o ́ \tau \rho o \varphi \alpha^{107}$, co podobnie jak i poprzednie stwierdzenie nawiązuje do ustaleń przełomu starożytności i wczesnego Bizancjum.

W końcu warto przyjrzeć się informacjom na temat interesującego nas produktu w Syntagma de alimentorum facultatibus Symeona Setha, który nie poświęcił omawianemu zbożu wiele swej uwagi, zapewne dlatego, że w XI w. ciągle nie zmieniło ono swego miejsca na liście popularnych produktów zbożowych wschodniej części basenu Morza Śródziemnego. Uwypuklił zatem jedynie dwie jego właściwości, a mianowicie zdolność do ochładzania i cechy ściągające ${ }^{108}$.

$\mathrm{Na}$ trwałość tradycyjnych doktryn wskazuje także rozdział omawiający owies z Appendiksu drukowanego wraz ze wspomnianymi Syntagma Symeona Setha. Jest on po prostu wypisem z księgi I Collectiones medicae Orybazjusza, a w ten sposób sięga też swymi korzeniami do ustaleń Galena z De alimentorum facultatibus ${ }^{109}$.

3. Owies i jego zastosowania w sztuce kulinarnej. Owies zarówno w starożytności jak i w epoce bizantyńskiej nie był powszechnie wykorzystywany $\mathrm{w}$ gastronomii. Wniosek ten można wysnuć nie tylko z bezpośrednich uwag

${ }^{104}$ Por. Paulus Aegineta, Epitomae medicae lib. VII 3, 2, 77-79; w niniejszym opracowaniu posługiwano się wydaniem: Paulus Aegineta, ed. I.L. Heiberg, I-II, Lipsiae - Berolini 1921-1924.

105 Traktat zapewne należy przypisać ogólnej aktywności twórczej stymulowanej przez Konstantyna VII Porfirogenetę, która wydała także dzieło Geoponika. Na temat kręgu, w którym po-

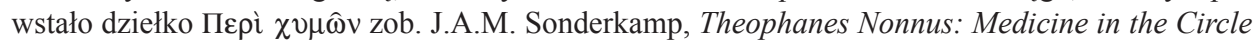
of Constantine Porphyrogenitus, DOP 38 (1984) 29-41.

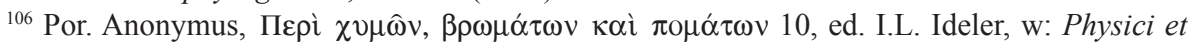
medici Graeci minores, II, Amsterdam 1963, 263.

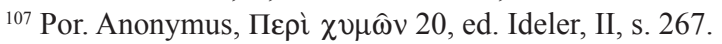

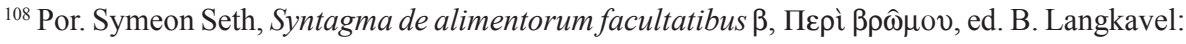
Simeonis Sethi Syntagma de alimentorum facultatibus, Lipsiae 1868, 30.

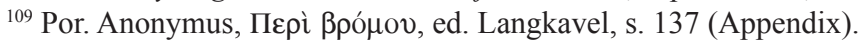


ówczesnych autorów na ten temat ${ }^{110}$, ale także $\mathrm{z}$ braku szczegółowych receptur kulinarnych uwzględniających ten produkt ${ }^{111}$. $\mathrm{Z}$ tego powodu, by wyobrazić sobie sposoby przygotowywania z niego potraw, musimy najczęściej odwoływać się do analogii związanych z przyrządzaniem innych produktów zbożowych, które to dane na szczęście zachowała literatura kulinarna i medyczna interesującej nas epoki.

$\mathrm{Z}$ ogólnych danych wiadomo, że $\mathrm{z}$ owsa sporządzano pokarmy płynne o rzadkiej konsystencji, dalej papki, czy też bardzo gęste zupy, na przykład

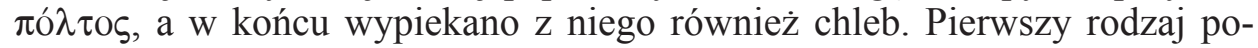
traw określano wieloma różnymi terminami. Analizowane w niniejszym studium źródła wskazują, że w tym celu używano nazw takich jak: $\dot{\alpha} \pi o ́ \zeta \varepsilon \mu \alpha^{112}$,

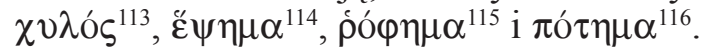

Termin $\alpha \pi o ́ \zeta \varepsilon \mu \alpha$ pojawia się $\mathrm{w}$ kontekście przetwarzania owsa, gdy Aleksander z Tralles pisze o różnego rodzajach wywarów (czy może odwaró$\mathrm{w})^{117}$, w których wykorzystywano całą gamę surowców (niekoniecznie zresztą zbożowych), w celu uzyskania z nich produktów, które - zachowując wartość pokarmową - mogły być także zastosowane w terapeutyce. Autor Therapeutica utrzymywał, że za jego czasów istniała już długa tradycja użycia różnorodnych odwarów w medycynie. Ponieważ rzadkim roztworem z $\pi \tau 1 \sigma \alpha ́ v \eta^{118}$, któ-

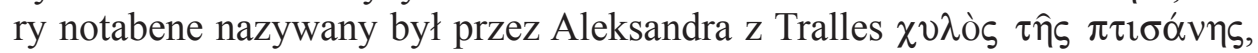
posługiwał się w leczeniu już sam Hipokrates, dlatego inni, jakby idąc w jego ślady, również korzystali szeroko z produktów należących do kategorii $\alpha$ ó $\mathrm{o}$ -

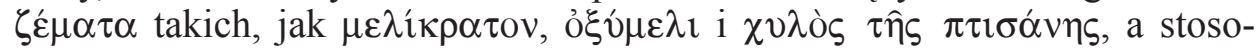
wano je głównie do ułatwienia wydalenia flegmy zalęgającej w oskrzelach. Ostatnim z wymienionych $\alpha \dot{\pi} \mathrm{o} \zeta \varepsilon_{\mu} \mu \alpha \tau \alpha$ lekarze posługiwali się zwłaszcza, gdy wydzielina z układu oddechowego miała cechy żółci. Dodał też, że jeżeli ktoś

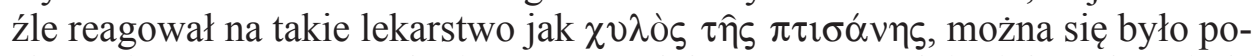
służyć innym typem analogicznego produktu, a szczególnie, jak podpowiada

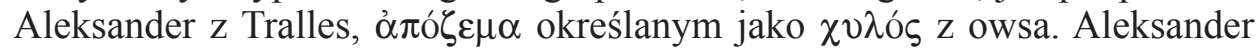
nie precyzował przepisu na rzeczone lecznicze pokarmy. Dodał tylko uwagę, że o konsystencji takiego produktu ${ }^{119}$, decydowała jego skuteczność działania, to znaczy zdolność usuwania wydzielin z klatki piersiowej i płuc ${ }^{120}$.

${ }^{110}$ Dobrym przykładem są uwagi Galena i Orybazjusza (cytowane powyżej), a które dotyczą niskiego prestiżu tego pokarmu wśród ludności zamieszkującej basen Morze Śródziemnego.

${ }^{111}$ Brak owsa w De re coquinaria.

${ }_{112}$ Por. Alexander Trallianus, Therapeutica II 241, 13 - 243, 5.

${ }_{113}$ Por. tenże, De febribus I 371, 9-10.

${ }^{114}$ Por. Oribasius, Collectiones medicae IV 6, 1, 1.

${ }^{115}$ Por. tenże, Synopsis ad Eustathium filium IV 35, 19, 1.

${ }^{116}$ Por. tenże, Collectiones medicae IV 6, 1, 1.

${ }^{117}$ Por. Liddell - Scott, s. 198, s.v. ỏ $\pi$ ó $\varepsilon \mu \alpha$.

${ }^{118}$ Zupa lub wywar z kaszy jęczmiennej. O terminie tym poniżej.

${ }^{119}$ Por. Alexander Trallianus, Therapeutica II 241, 21-23.

${ }^{120}$ Por. tamże II 241, 13-21. 
Gdy chodzi o termin $\chi v \lambda o ́ \varsigma^{121}$, z rozważań Aleksandra z Tralles wnioskować wypada, że semantycznie mógł on stanowić zamiennik omówionego już wyrazu $\alpha \dot{\alpha} \operatorname{có}_{\varepsilon} \varepsilon \alpha$. Na podstawie analizowanych danych konstatujemy też, iż sam produkt, oprócz użycia go jako sui generis syropu, mógł być stosowany jako zasadnicza część pożywienia. Stanowił on bowiem dietę odpowiednią dla cierpiących, na przykład dla tych, którzy gorączkują ${ }^{122}$, lub takich, którym doskwierają stany chorobowe wątroby ${ }^{123}$. Przepis na rzeczony odwar nie został sprecyzowany. Można się jednak spodziewać, iż nie odbiegał daleko od receptury na pó $\varphi \eta \mu \alpha$, która cytowana jest poniżej w niniejszym artykule. Wydaje nam się także prawdopodobne, iż dobrą analogię służącą do przybliże-

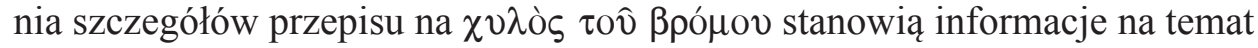

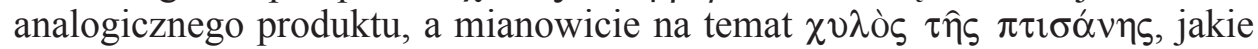
znajdujemy u Orybazjusza, a które ten ostatni zapożyczył z pism Antyllosa ${ }^{124}$. Rzeczony $\chi 0 \lambda o ́ \varsigma$ uzyskiwano, rozcieńczając $\pi \tau \imath \sigma o ́ v \eta$ wodą, a uzyskany tak roztwór redukując o jedną piątą. Przed podaniem do picia płyn cedzono ${ }^{125}$.

Termin ع̌ $\psi \eta \mu \alpha$, który odnajdujemy w Collectiones medicae Orybazjusza, a który został $\mathrm{w}$ omawianym przez nas kontekście zapożyczony przez tego słynnego lekarza od Dieuchesa, nie był zapewne odległy w swym znaczeniu od poprzednio użytych. Odnosił się bowiem do wszystkich produktów i potraw, które powstały w wyniku gotowania ${ }^{126}$. Określenie konsystencji nie było cechą immanentną omawianego greckiego pojęcia, a więc mogła się wahać od rzadkiej do gęstej. Wnioskować zatem wypada, że w zakres tego terminu wchodziły zarówno rzadkie $\alpha \dot{\alpha} \mathrm{\zeta} \zeta \dot{\varepsilon} \mu \alpha \tau \alpha$ (ex difinitione otrzymane w wyniku

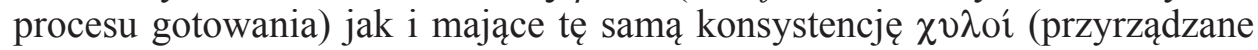
analogiczne, to znaczy przez poddanie różnorodnych produktów procesowi obróbki termicznej z dodatkiem wody). $Z$ racji na rozległość zakresu pojęciowego terminu ع̌ $\psi \eta \mu \alpha$, mogły się jednak także w nim mieścić gęstsze, ale

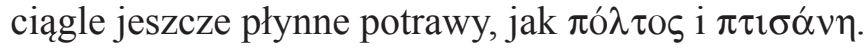

Jeżeli odwołamy się do konkretnych stwierdzeń Dieuchesa i Orybazjusza na temat $\dot{\varepsilon} \psi \hat{\eta} \mu \alpha \tau \alpha$, to dowiadujemy się, że owe wywary/potrawy mogły powstać w wyniku gotowania kaszy otrzymanej z różnych zbóż, na przykład, krup typu ö $\lambda \varphi \imath \tau o v / \not \alpha \lambda \varphi \imath \tau \alpha$, które z kolei wyrabiane były zwykle z ziaren jęczmienia. Wrzucano je na $\mathrm{z}$ wolna gotujący się wywar, na przykład na rosół kurzy. Nie należało ich mieszać, ale trzeba było pozwolić im powoli nabierać miękkości w wyniku stopniowego podgrzewania bezpośrednio na ogniu lub na łaźni wodnej do momentu aż owa kasza stanie się gotowa. Z rozważań medyków dowiadujemy się także, że dodawano $\alpha{ }^{\prime} \lambda \varphi \imath \tau \alpha$ do rosołu baraniego, koźle-

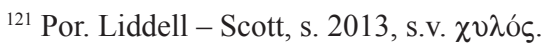

${ }^{122}$ Bardziej szczegółowe informacje na ten temat poniżej.

${ }^{123}$ Bardziej szczegółowe informacje na ten temat poniżej.

${ }^{124}$ Por. Oribasius, Collectiones medicae IV 11, 1, 1 - 14, 4.

125 Por. tamże IV 11, 4, 1-4.

${ }^{126}$ Por. Liddell - Scott, s. 751, s.v. ع̋ $\psi \eta \mu \alpha$.
} 
go, najlepiej dość tłustego, oraz do wywaru z młodej wieprzowiny ${ }^{127}$. Lekarz nic nie pisał o przepisach na rosoły mięsne, które wymienione zostały w recepturze na $\varepsilon \psi \eta \mu \alpha$ z $\alpha$ $\lambda \varphi \imath \tau \alpha$. Sposób, w jaki przygotowywano owe wywary,

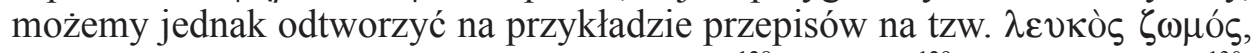
zamieszczonych $w$ traktatach Dioskuridesa ${ }^{128}$, Galena ${ }^{129}$ i Orybazjusza ${ }^{130}$. Czytamy w nich, że do garnka z wodą dodawano najlepszego gatunku oliwę, koper ogrodowy oraz nieco pora. Do tego wkładano umyte mięso i całość gotowano z dodatkiem soli. Dosypywano ją na początku, bądź w momencie, gdy mięso było na wpół miękkie ${ }^{131}$. O tym, że omawiana receptura cieszyła się popularnością i przygotowywane według niej potrawy jedzone były nie tylko ze względu na właściwości zdrowotne świadczy, niestety niekompletny, przepis na kurczaka w białym sosie (pullus leucozomus), który zamieszczony został w De re coquinaria. $\mathrm{Z}$ zachowanych fragmentów wynika, że sprawione mięso kurczaka z otwartą klatką piersiową, umieszczano w naczyniu, wypełnionym wodą z dodatkiem hiszpańskiej oliwy. Do tego dokładano pora i gotowano ${ }^{132}$.

Z rozważań zachowanych w Collectiones medicae wynika także, iż można też było ugotować potrawę charakteru podobnego do opisanego ع́ $\psi \eta \mu \alpha$, lecz nie na rosole mięsnym, ale na wodzie $\mathrm{z}$ dodatkiem mleka. Receptura przewidywała wtedy połączenie ćwierć chous $^{133}$ dobrej kaszy ö́ $\lambda \varphi \imath \tau \alpha$ z dwiema kotyle ${ }^{134}$ mleka, a następnie dolanie do obu składników dodatkowo jednej trzeciej objętości wody, a nadto dosypanie tyle uprażonego maku, ile mieści się w makówce. Do wyspecyfikowanej mieszaniny wrzucano także trzy obole $e^{135}$ rozdrobnionych fig, a po ugotowaniu całość uzyskiwała konsystencję płynu nadającego się do wypicia, który autorzy tej receptury nazwali ṕó $\varphi \eta \mu \alpha^{136}$.

Choć termin ő $\lambda \varphi \imath \tau \alpha$, jak było to już zaznaczone, zwykle odnosił się do wyrobu z jęczmienia, całość powyżej przytoczonych danych winna zająć poczesne miejsce w naszych rozważaniach na temat kulinarno-medycznych zastosowań owsa, ponieważ od Dieuchesa i Orybazjusza dowiadujemy się, iż kaszę typu ő̉ $\lambda \varphi \imath \tau \alpha$ wytwarzano także z owsa. Obaj dają nawet wskazówki dotyczące jej produkcji. By ją otrzymać, zboże prażono w łuskach, a następnie oczyszczano oraz mielono, tak jak to się zwykle postępowało w przypadku

${ }^{127}$ Oribasius, Collectiones medicae IV 6, 1, 1 - 2, 1.

${ }^{128}$ Por. Dioscurides Pedanius, De materia medica II 33, 1, 1-5.

${ }^{129}$ Por. Galen, De alimentorum facultatibus lib. 725, 6-13.

${ }^{130}$ Por. Oribasius, Collectiones medicae II 51, 6, 1 - 7, 3.

${ }^{131}$ Por. Kokoszko, Smaki Konstantynopola, s. 496, nota 160.

${ }^{132}$ Por. Apicius, De re coquinaria VI 8, 15; w niniejszym opracowaniu posługiwano się wydaniem: Apicius, A Critical Edition with an Introduction and an English Translation of the Latin Recipe Text Apicius, Text and Commentary Ch. Grocock - S. Grainger, Totnes 2006; tłum. I. Mikołajczyk - S. Wyszomirski: Apicjusz, O sztuce kulinarnej ksiag dziesięć, Toruń 1998.

${ }^{133}$ Chous $=12$ kotylai .

${ }^{134}$ Kotyle $=6$ kyathoi .

${ }^{135}$ Obol-0, 73 g.

${ }^{136}$ Por. Oribasius, Collectiones medicae IV 6, 2, 1 - 4, 1. 
kaszy ơ $\lambda \varphi \imath \tau \alpha$ z jęczmienia. Nadto obaj medycy zamieścili w swych dziełach informację, iż o̊ $\lambda \varphi \imath \tau \alpha$ z owsa są lepsze od jęczmiennych i powodują powstawanie w organizmie mniejszej ilości gazu ${ }^{137}$.

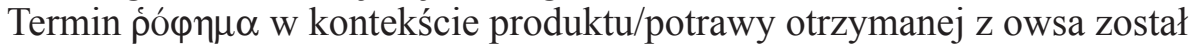
wykorzystany już przez Hipokratesa i jego szkołę. Znaczenie tego rzeczownika można wyczytać z przeciwstawienia tego określenia w De diaeta pasywnemu participium od $\varepsilon^{\sigma} \sigma \theta^{\prime} \omega^{138}$. Nieco więcej informacji na temat $\rho \circ \varphi \eta \mu \alpha \tau \alpha$ z owsa zachowuje dla nas Orybazjusz w tych częściach swoich prac, które są kolejnymi wypisami z Dieuchesa. Mianowicie w 'Eк $\tau \hat{\omega} \nu \Delta \imath \varepsilon v ́ \chi 0 v \varsigma, \pi \varepsilon p i$ $\tau \rho о \varphi \hat{\omega} v \sigma \kappa \varepsilon v \alpha \sigma i \alpha \varsigma^{139}$ czytamy, iż owies jest najłatwiejszy do strawienia spo-

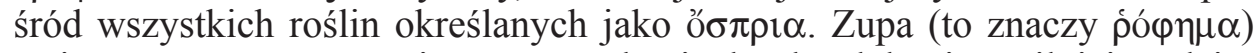
z niego przygotowywana jest ze wszech miar bardzo dobra i ma silniejsze działanie niż analogiczna potrawa sporządzana z prażonego jęczmienia. Wpływa ona natomiast na organizm słabiej od $\pi \tau 1 \sigma \alpha ́ v \eta$, ale jest od niej smaczniejsza. Co bardzo istotne, fragment Collectiones medicae zawiera przepis na sporządzanie owsianego pó $\varphi \eta \mu \alpha$. Jak twierdzi autor, danie takie gotuje się tak jak $\pi \tau$ $\sigma \alpha ́ v \eta$, łącząc jedną kotyle owsa $\mathrm{z}$ dziesięcioma kotylai wody ${ }^{140}$. Biorąc pod uwagę wyspecyfikowane w źródle proporcje płynu do kaszy, jesteśmy w stanie zaryzykować opinię, iż powstałe danie było czymś w rodzaju kleiku owsianego, który zapewne możliwy był do wypicia.

Termin $\pi$ ó $\tau \mu \alpha$ z kolei odnosił się w języku greckim do napoju każdego typu $^{141}$. Zapewne w kontekście naszych rozważań na temat owsa mógł on być użyty $\mathrm{w}$ znaczeniu jakiegokolwiek płynnego produktu powstałego $\mathrm{z}$ dodatkiem lub w wyniku przerobu omawianego zboża, a przynajmniej ani Dieuches ani Orybazjusz nie nadali mu innej, specyficznej wartości semantycznej. Omawiając termin $\pi 0 \tau \eta ́ n \mu \alpha \alpha$ warto też przypomnieć, iż napoje, które jednocześnie w swej istocie stanowiły także pożywne potrawy, miały w tradycji kuchni greckiej ugruntowaną pozycję. Przykładem niech będzie słynny, gdyż

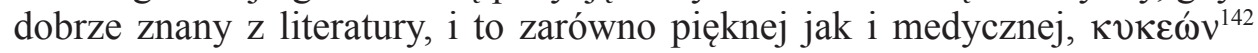
zaświadczony już w Homeryckich eposach. Jak pisał poeta, przygotowywano go, dodając do parmeńskiego wina miód, kaszę jęczmienną oraz pokruszony kozi ser. Napitek można było przegryzać gorącą, być może pieczoną, cebu-

${ }^{137}$ Por. tamże IV 6, 4, 1-5.

${ }^{138}$ Zostało ono użyte przez autora wymienionego dzieła zapewne dla oznaczenia czynności spożywania pokarmów stałych albo też gęstych papek przygotowanych na bazie owsa. Zob. definicję przedstawioną w Liddell - Scott (s. 1575, s.v. pó $\varphi \eta \mu \alpha)$, która nie wydaje się nazbyt precyzyjna wobec materiału zawartego w analizowanych w niniejszym artykule źródłach medycznych.

${ }^{139}$ Oribasius, Collectiones medicae IV 7, 1, $1-38,4$.

${ }^{140}$ Por. tamże IV 7, 20, 1 - 21, 1.

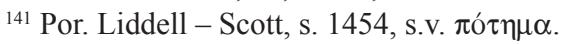

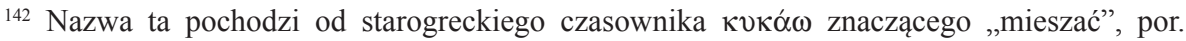
A. Dalby, Food in the Ancient World from A to Z, London - New York 2003, 191; Abramowiczówna II 729, s.v. кטкع́́v. 
lą $^{143}$. Z Odysei dowiadujemy się, że kykeonowi przypisywano właściwości magiczne, które dziś nazwalibyśmy raczej narkotycznymi. Czarodziejka Kirke bowiem uraczyła towarzyszy Odyseusza tą właśnie miksturą, przyprawioną ponadto dodatkiem ,zgubnych ziół”, by zapomnieli o ojczystej ziemi, a następnie za dotknięciem różdżki zmieniła ich w świnie ${ }^{144}$. O innej, tym razem rytualnej, ale również „magicznej” roli kykeonu poinformował nas autor In Cererem (Hymn do Demeter). Bogini, w czasie poszukiwań córki zachowywała post, który zakończyła po dotarciu do domu Keleosa. Tam, stwierdzając, że nie godzi się jej, będąc w stanie tak wielkiej żałoby, pić czerwonego wina, kazała podać sobie wodę zmieszaną z mąką i miętą ${ }^{145}$, a więc inną, swoistą formą kykeonu tyle, że pozbawioną owego szlachetnego trunku. W starożytnej Grecji napój tego typu kojarzony był nierozerwalnie z obchodami misteriów eleuzyńskich. Tradycja nakazywała, by każdy wtajemniczony po uprzednim okresie głodówki skosztował tak przygotowanego napitku ${ }^{146}$. Główną (prócz odżywczych) cechą rzeczonego napoju było pobudzenie uczestników rytuału. Jego skuteczność była gwarantowana, ponieważ prażony jęczmień, dodany do wody przemieniał się w słód, który nadawał napojowi słodki smak, a po procesie fermentacji przekształcał się w alkohol. Do napoju dokładano, zgodnie ze wskazówkami hymnu, „delikatne”, tzn. świeże, liście mięty polej (Mentha pulegium L.). Wypicie przyrządzonego wedle tej receptury kykeonu, połączone z wcześniejszą głodówką miało, prawdopodobnie, wywołać halucynacje u Greków uczestniczących w misteriach ${ }^{147}$.

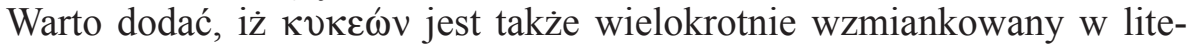
raturze medycznej jako potrawa nie tylko o różnorodnym składzie, ale też wielu zastosowaniach terapeutycznych. Jak utrzymuje autor De diaeta, właściwości omawianego napoju zmieniały się w zależności od komponentów. Przygotowany z mąki jęczmiennej i wody ochładzał i odżywiał organizm, natomiast $\mathrm{z}$ dodatkiem wina rozgrzewał, odżywiał i nabierał właściwości ściągających. $Z$ kolei jeśli składnikiem potrawy był dodatkowo miód, stawała się ona mniej rozgrzewająca i odżywcza. Gdy miód był rozwodniony, mikstura działała przeczyszczająco, a jeśli był czysty, napój spowalniał pracę przewodu

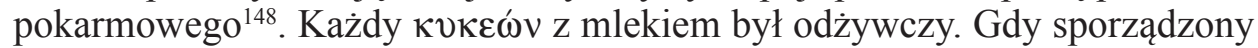
został z mlekiem krowim, zatrzymywał pracę jelit. Mleko kozie bardziej stymulowało pracę przewodu pokarmowego, podczas gdy owcze charakteryzo-

${ }^{143}$ Por. Homerus, Ilias IX 630-641; w niniejszym artykule posługiwano się wydaniem: Homer. The Iliad, with an English Translation by A.T. Murray, London - Cambridge Mass. 1960-1963.

144 Por. Homerus, Odyssea X 233-240; w niniejszym artykule posługiwano się wydaniem: Homeri Odyssea, cum potiore lectionis varietate, ed. A. Nauck, Homerica carmina 2, Berolini 1874.

${ }^{145}$ Por. In Cererem 206-210; w niniejszym artykule posługiwano się wydaniem: The Homeric Hymns, ed. T.W. Allen - W.R. Halliday - E.E. Sikes. Oxford 1936; thum. W. Appel (Hymn do Demeter) w: Homeriká, czyli żywoty Homera i poematy przypisywane poecie, Warszawa 2007.

${ }^{146}$ Por. K. Kerényi, Eleusis. Archetypowy obraz matki i córki, tłum. I. Kania, Kraków 2004, 74.

${ }^{147}$ Por. tamże, s. 223-225.

${ }^{148}$ Por. Hippocrates, De diaeta 41, 1. 
wało się analogicznym działaniem, ale w mniejszym stopniu. Mleko końskie i ośle z kolei doprowadzało do szybszego przeczyszczenia ${ }^{149}$.

$\mathrm{Z}$ czasem, jak podaje Galen ${ }^{150}$ oraz żyjący na przełomie V i VI w. leksy-

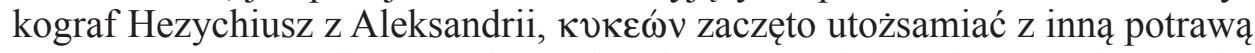
przygotowywaną z $\alpha^{\prime \prime} \lambda \varphi \imath \tau \alpha$ (których substytutem, jak to już zostało powiedziane, zapewne mógł być też owies), mianowicie z grecką $\pi \tau 1 \sigma \alpha ́ v \nu \eta^{151}$, która po łacinie zwana była tisana ${ }^{152}$. Jej popularność była trwała, o czym świadczy fakt, że o analogicznej zupie pisze jeszcze Symeon Seth (XI w. $)^{153}$.

Czym zatem była $\pi \tau \iota \sigma \alpha ́ v \eta ? ~ Z$ danych wynika, iż to danie o leczniczym działaniu, mające konsystencję napoju bądź zupy-kleiku, przyrządzano głównie z kaszy jęczmiennej ${ }^{154}$. Z zapisków Galena (oraz cytującego go Orybazjusza) dowiadujemy się, że przygotowywano je z namoczonych, oczyszczonych z łusek ziaren, które gotowano w wodzie (z dodatkiem octu winnego i oliwy) na wolnym ogniu do momentu napęcznienia. Gdy zboże stawało się miękkie przyprawiano je drobną solą, a czasem porem i koprem włoskim ${ }^{155}$. Tak powstały posiłek oczyszczał ${ }^{156}$ i nawilżał ${ }^{157}$ organizm. Żyjący w VI w. lekarz Antimus, który skomponował traktat De observatione ciborum, pisał także o wpływie tej potrawy zarówno na osoby zdrowe jak i cierpiące na febrę ${ }^{158}$, a informacje przez niego utrwalone jasno wskazują, że pokarm ten przygotowywany był nie tylko jako medykament, ale mógł też stanowić wartościowy, codzienny posiłek. Dowodem na ten ostatni fakt są przepisy na tisanam vel sucum pochodzące z De re coquinaria, które warte są przytoczenia, by zilustrować różnorodność składników potrawy i możność zastosowania rozmaitych przepisów.

Zgodnie z pierwszą recepturąi59, na dzień przed przygotowaniem, kaszę jęczmienną trzeba było namoczyć, wypłukać i utrzeć w moździerzu. Kolejnego dnia należało włożyć ją do garnka, który stawiano na dużym ogniu, następnie dodać odpowiednią ilość oliwy, mały pęczek kopru, suszoną

\footnotetext{
${ }^{149}$ Por. tamże 41, 1-7.

${ }^{150}$ Por. Galenus, De alimentorum facultatibus lib. 503, 8-10.

${ }^{151}$ Por. Hesychius, Lexicon, $\pi \tau \imath \sigma \alpha ́ v \eta, \pi, 4230,1$.

${ }^{152}$ Por. Dalby, Food in the Ancient World, s. 191. Pierwsza z nazw jest grecka - † $\pi \tau \iota \sigma \alpha ́ v \eta$, druga - łacińska.

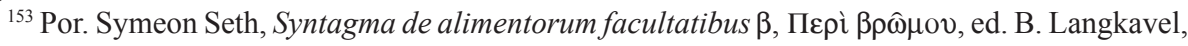
s. 30 .

${ }^{154}$ Por. Dalby, Food in the Ancient World, s. 46.

${ }^{155}$ Por. Galenus, De alimentorum facultatibus lib. 502, 7 - 504, 4. Na temat rozważań diete-

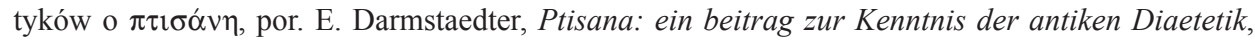
„Archeion” 15 (1933) 181-201.

${ }^{156}$ Por. Aetius Amidinus, Iatricorum lib. II 260, 1.

${ }^{157}$ Por. tamże I 225, 11-12.

${ }^{158}$ Por. Anthimus, De observatione ciborum 64 . O innych zastosowaniach podobnych potraw por. poniżej.

${ }^{159}$ Por. Apicius, De re coquinaria IV 4, 1.
} 
cebulę, cząber ogrodowy i golonkę. Całość gotowano do momentu otrzymania zupy, następnie dokładano do niej utartą wraz z solą zieloną kolendrę. Po ponownym zagotowaniu należało wyjąć z zupy pęczek kopru, a kaszę przełożyć do innego, umieszczonego na ogniu, garnka, w którym ponownie ucierano ją w taki sposób, by nie przywarła do niego i nie przypaliła się. Następnie masę przekładano do naczynia z golonką i dodawano mieszaniny z utartego pieprzu, lubczyku ogrodowego, suszonej mięty polej, kminu rzymskiego, asafetydy, octu, gotowanego moszczu winnego (defritum) i sosu ze sfermentowanych ryb (garum/liquamen). Całość gotowano potem na wolnym ogniu, a następnie serwowano.

$\mathrm{W}$ kolejnym przepisie $\mathrm{z}$ tego samego zbioru $^{160}$ zalecano dodanie do zupy namoczonych warzyw strączkowych: ciecierzycy, soczewicy i grochu. Gotowano je wraz z oczyszczoną kaszą jęczmienną do zmięknięcia. Następnie dolewano oliwy i dokładano drobno pokrojonych warzyw: pora, kolendry, kopru ogrodowego, kopru włoskiego, buraka, malwy, młodych łodyżek kapusty. W osobnym naczyniu należało gotować w wodzie łodyżki kapusty wraz z utartymi nasionami kopru włoskiego, lebiodką pospolitą, asafetydą i lubczykiem ogrodowym. Następnie doprawiano zupę sosem ze sfermentowanych ryb (garum/liquamen) i ucierano składniki. Tak przygotowaną płynną pulpę trzeba było jeszcze połączyć z ugotowanymi wcześniej ziarnami jęczmienia i roślinami strączkowymi. Danie serwowano z drobno pokrojonymi łodyżkami kapusty.

Interesujący i uzupełniający powyższe dane przepis znajdujemy także w literaturze czysto medycznej. Paweł z Eginy mianowicie utrzymywał, iż w celach leczniczych przygotowuje się sui generis zupę, dając jedną część kaszy na piętnaście części wody i dolewając do niej oliwy, a gdy już napęcznieje, także octu. Po ugotowaniu dorzucano nadto nieco pora i kopru. Przedstawiwszy ten przepis dodaje, iż podobnie do takiej właśnie $\pi \tau \imath \sigma \alpha ́ v \eta(\pi \alpha \rho \alpha \pi \lambda \eta \sigma i \omega \varsigma \delta \varepsilon \tau \hat{n}$ $\pi \tau \imath \sigma \alpha ́ v \eta ̣)$, gotuje się także owies oraz $\chi o ́ v \delta \rho o \varsigma^{161}$.

Te ostatni termin oznacza kolejny rodzaj kaszy, tym razem sporządzanej zwykle z pszenicy płaskurki lub pszenicy zwyczajnej ${ }^{162}$. Tak jak w przypadku

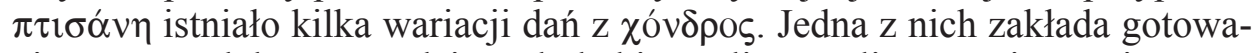
nie tego produktu $\mathrm{w}$ wodzie $\mathrm{z}$ dodatkiem oliwy, soli oraz wina zmieszanego z miodem (oỉvó $\mu \varepsilon \lambda \imath$ ) lub samego tego trunku. Aby uniknąć przypalenia gęstej potrawy należało ją mieszać przez cały czas gotowania. Inny przepis mówi o doprawieniu podobnej gęstej zupy octem winnym. Nazywana była ona wówczas $\chi o ́ v \delta \rho o \varsigma ~ \pi \tau \imath \sigma \alpha \nu \imath \sigma \tau i$, a termin ten nawiązywał do omawianego wcześniej dania, czyli $\pi \tau \iota \sigma \alpha ́ v \eta^{163}$.

${ }^{160}$ Por. tamże IV 4, 2.

${ }^{161}$ Paulus Aegineta, Epitomae medicae lib. I 78, 1, 21-25.

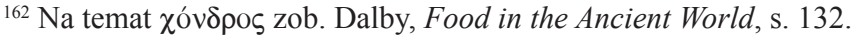

${ }^{163}$ Por. Oribasius, Collectiones medicae I 5, 1, 1 - 2, 2. Zob. Kokoszko, Smaki Konstantynopola,

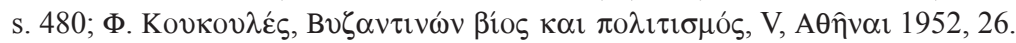


Znawcy antycznej gastronomii wśród potraw zbożowych mających konsystencję pomiędzy bardzo gęstą zupą a papką wymieniają jeszcze $\pi$ ó $\lambda \tau o \varsigma^{164}$. Danie to jest dla nas szczególnie ważne w kontekście tematu niniejszych rozważań, ponieważ - jak było to już wzmiankowane - Pliniusz w swej Historia naturalis zaznaczy1, że Germanie żywili się tego typu potrawą przygotowaną $\mathrm{z}$ ziaren owsa ${ }^{165}$. Na podstawie cytowanych już powyżej uwag Galena z De alimentorum facultatibus oraz Orybazjusza z jego Collectiones medicae możemy domyślać się jednakże, że praktyka ta nie była ograniczona jedynie do Germanii, ale podobne danie gotowali z owsa także mieszkańcy obszarów śródziemnomorskich. Gdy dla Germanów jednak posiłek taki stanowił pożywienie codzienne, a - jak sugeruje to Antimus - właściwe także dla elit arystokratycznych, mieszkańcy basenu Morza Śródziemnego sporządzali go tylko $\mathrm{z}$ powodu braku ${ }^{166}$ innych, bardziej cenionych przez nich zbóż ${ }^{167}$.

I w tym przypadku, chcąc zrekonstruować przepis na $\pi$ ó $\lambda \tau o \varsigma$, ponownie musimy posłużyć się analogią do receptury, w której głównym składnikiem jest kasza z innego rodzaju zboża, mianowicie krupy z pszenicy płaskurki, czyli ở $\lambda \imath \xi$ (łac. alica) ${ }^{168}$. Posiłek taki mógł być przygotowany z rozdrobnionych ziaren gotowanych na wodzie ${ }^{169}$ lub mleku ${ }^{170}$. Z informacji, jakie przekazuje nam Aecjusz z Amidy ${ }^{171}$, dowiadujemy się, że - aby go uwarzyć - należało ugotować kaszę w wodzie doprawionej solą, oliwą i koprem ogrodowym. Czasem oliwę zastępowano świeżym tłuszczem, kurzym lub gęsim ${ }^{172}$.

O powszechności tej potrawy mogą świadczyć przepisy zawarte w De re coquinaria $^{173}$. Jeden z nich wart jest omówienia ze względu na sposób przygotowania, jak i szerszą gamę składników od tej, którą podawał Aecjusz z Amidy. Anonimowy autor łacińskiej receptury zaproponował, by przesianą i namoczoną kaszę z pszenicy płaskurki gotować do momentu, aż zacznie mięknąć. Potem trzeba do niej dodać oliwy i trzymać na ogniu dopóki nie

${ }^{164}$ Por. Dalby, Food in the Ancient World, s. 271 (charakterystyka terminu puls). Potrawa ta była szeroko rozpowszechniona w kulturze grecko-rzymskiej. Spotykamy ja także na Wyspach Brytyjskich pod panowaniem Rzymian. Zob. H.E.M. Cool, Eating and Drinking in Roman Britain, Cambridge 2006, 75.

${ }^{165}$ Por. Plinius, Historia naturalis XVIII 44, 119; J. André, L'alimentation et la cuisine à Rome, Paris 1961, s. 56. Zob. Alcock, Food in the Ancient World, s. 34.

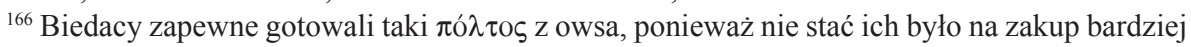
cenionych zbóż do przygotowania tej potrawy, gdy zamożniejsi uciekali się do wykorzystania owsa tylko wtedy, gdy na rynku występował brak jęczmienia, pszenicy płaskurki i innych produktów, które zwykle spożywali.

${ }^{167}$ Por. Wilkins - Hill, Food in the Ancient World, s. 119.

${ }^{168}$ Kasza z pszenicy płaskurki. Por. Dalby, Food in the Ancient World, s. 127.

${ }^{169}$ Woda występuje w cytowanym niżej przepisie Aecjusza z Amidy oraz w De re coquinaria.

${ }^{170}$ Por. Hesychius, Lexicon, $\Gamma \alpha \lambda \alpha \dot{\xi} \iota \alpha, \gamma, 80$, 2. Inne przykłady poniżej.

${ }^{171}$ Por. Aetius Amidinus, Iatricorum lib. IX 42, 62.

${ }^{172}$ Por. tamże IX 42, 62-66.

${ }^{173}$ Por. Apicius, De re coquinaria V 1, 1-4. 
zgęstnieje, a następnie dokładnie rozetrzeć. W moździerzu należało też utrzeć dwa gotowane móżdżki i pół libry siekanego mięsa. Masę tę łączono z utartymi przyprawami, takimi jak pieprz, lubczyk ogrodowy, nasionami kopru włoskiego, oraz z płynami, winem i garum/liqamen. Mieszaninę tę gotowano na wolnym ogniu, by wszystkie aromaty połączyły się ze sobą. Gotową i gorącą masę stopniowo dodawano do kaszy ${ }^{174}$.

$\mathrm{Z}$ owsa wypiekano także chleb. Jak to już zostało wspomniane, nie była to procedura zwyczajna. Uciekano się do niej jedynie wtedy, gdy brak było innych zbóż lepiej nadających się do tego celu, a zwłaszcza gdy miał miejsce nieurodzaj pszenicy, która stanowiła najwartościowszy surowiec do wyrobu tego rodzaju pieczywa. Chleb owsiany nie był ceniony, a Galen pisał o jego smaku z niechęcią. Tym niemniej jedzono go czasami, o czym świadczą przytoczone powyżej oceny dietetyczne tego pokarmu.

Na koniec warto przypomnieć także, iż traktat Geoponika informuje nas o tradycji sporządzania z owsa napoju alkoholowego, zapewne analogicznego do piwa ${ }^{175}$. Co prawda, przytaczając tę opinię, autor posługiwał się autorytetem Leontyna, a więc autora tworzącego w III w. ${ }^{176}$, jednak można domyślać się, że praktyka ta była permanentna i miała zastosowanie aż w X w., a więc do momentu skomponowania Geoponika.

4. Zastosowanie owsa w procedurach terapeutycznych. Wykorzystanie owsa w procedurach medycznych nie znalazło odzwierciedlenia w rozważaniach włączonych do Corpus Hippocraticum, mimo tego że autor traktatu De diaeta wymienił kilka cech omawianego zboża jako produktu mającego wpływ na stan zdrowotny człowieka.

Kilka sugestii na ten temat pozostawił nam natomiast Dioskurides. Po

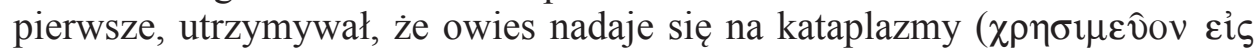
$\kappa \alpha \tau \alpha \pi \lambda \alpha \sigma \sigma \mu \alpha \tau \alpha)^{177}$. Domyślamy się, iż miały one działanie diaforetyczne i stosowane były samodzielnie lub z dodatkami w celu pozbycia się miejscowej dyskrasji humoralnej. Po drugie, dowiadujemy się od niego, iż z owsa sporządzano $\pi$ ó $\lambda \tau$ os, który doprowadza do zatrzymania pracy przewodu pokarmowego $(\sigma \tau \alpha \lambda \tau \imath \kappa o ̀ \varsigma ~ \kappa o \imath \lambda i ́ \alpha \varsigma) ~)^{178}$. W związku z tym sądzimy, że można go było wykorzystywać we wszelkich schorzeniach przewodu pokarmowego wymagających spowolnienia pracy jelit, a zwłaszcza w niedomaganiach, które objawiały się biegunkami świadczącymi o dyzenterii ${ }^{179}$. Po trzecie, z omawia-

${ }^{174}$ Por. tamże V 1, 1. W dziełku zawarty jest też przepis na pultes ,na słodko” (pultes tractogalatae) z dodatkiem m.in. mleka i miodu, por. Apicius, De re coquinaria V 1, 3.

175 Por. Cassianus Bassus, Geoponica VII 34, 1.

${ }^{176}$ Por. Oder, Beiträge zur Geschichte der Landwirtschaft, s. 92-93.

177 Dioscurides Pedanius, De materia medica II 94, 1, 3-4. Por. rozważania Galena zamieszczone poniżej.

178 Tamże II 94, 1, 4-5.

${ }^{179}$ Por. rozważania Galena na temat właściwości omawianego zboża zamieszczone poniżej. 


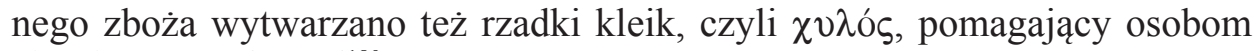
cierpiącym na kaszel ${ }^{180}$.

Galen w swych pracach powtarzał w zasadzie ustalenia Dioskuridesa. Twierdził on mianowicie, że owies jako lekarstwo ma właściwości podobne do tych, które posiada jęczmień. Użyty zewnętrznie, a więc jako składnik kataplazm, wysusza i umiarkowanie doprowadza do wydalenia produktów przemiany materii bez szkody dla organizmu. Nadto Galen odnosił się także do wewnętrznego stosowania owsa, ponieważ podkreślał, że dzięki naturalnej

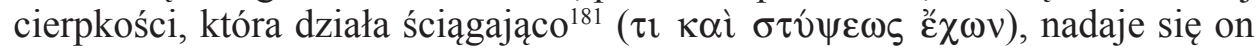

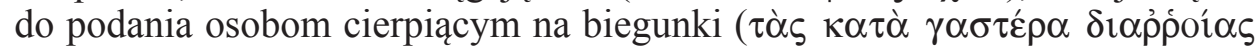
$\hat{\omega} \varphi \varepsilon \lambda \varepsilon \hat{\imath} v)^{182}$. Zapewne chodziło mu o wykorzystanie produktów otrzymanych $\mathrm{z}$ owsa, szczególnie różnorodnych zup typu $\pi$ ó $\lambda \tau$ $\tau$, w żywieniu chorych na dyzenterię, a być może także o jego zastosowanie w kuracjach w postaci płukanek i enem opartych na rzadkim wywarze typu $\chi 0 \lambda o ́ s$.

Orybazjusz, idąc za radami swoich poprzedników, również zwracał uwagę na to, że owies nadaje się na kataplazmy, które mają wyraźnie właściwości diaforetyczne ${ }^{183}$. Działanie to jest jednak na tyle delikatne, iż nie doprowadza do uszkodzenia tkanek organizmu ${ }^{184}$. Ponieważ uwypuklał on w swych pismach właściwości ściągające owsa ${ }^{185}$, wypada domyślać się, że również polecał go tam, gdzie potrzeba było lekarstw i pokarmów leczących dyzenterię. Hipotezę tę potwierdzają zresztą wypisy, które Orybazjusz zrobił z dzieła Dieuchesa. $\mathrm{W}$ jego rozważaniach dotyczących zasadniczo kaszy typu ơ $\lambda \varphi \imath \tau o v / \alpha{ }^{\prime} \lambda \varphi \imath \tau \alpha$, pisze bowiem, iż dodaje się ją do rosołu baraniego lub koźlego, najlepiej dość thustego, jak i do wywaru $\mathrm{z}$ młodej wieprzowiny, a takie danie dobre jest dla chorych na dyzenterię ${ }^{186}$. Z kolei $\alpha \dot{\alpha} \nu \iota \tau \alpha$ gotowane na mleku, z dodatkami takimi jak mak i figi, przynoszą uspokojenie ${ }^{187}$ i ograniczają produkcję moczu ${ }^{188}$. Co niezwykle istotne w kontekście niniejszych rozważań, z tekstu Collectiones medicae jasno wynika, że uwagi wyżej przedstawione dotyczą także owsa, gdyż autor wymienionego dzieła wyraźnie stwierdza, iż kasza typu ő $\lambda \varphi \imath \tau \alpha$ mogła być także i produkowana $\mathrm{z}$ owego niezbyt wysoko cenionego produk$\mathrm{tu}^{189}$. Nadto Orybazjusz z pewnością widział zastosowanie omawianego zboża w leczeniu dolegliwości klatki piersiowej. Dowodem na to jest jego zaintereso-

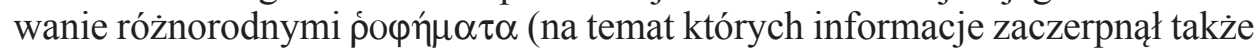
z dorobku Dieuchesa), przygotowywanymi z owsa. Dodać jedynie wypada, że

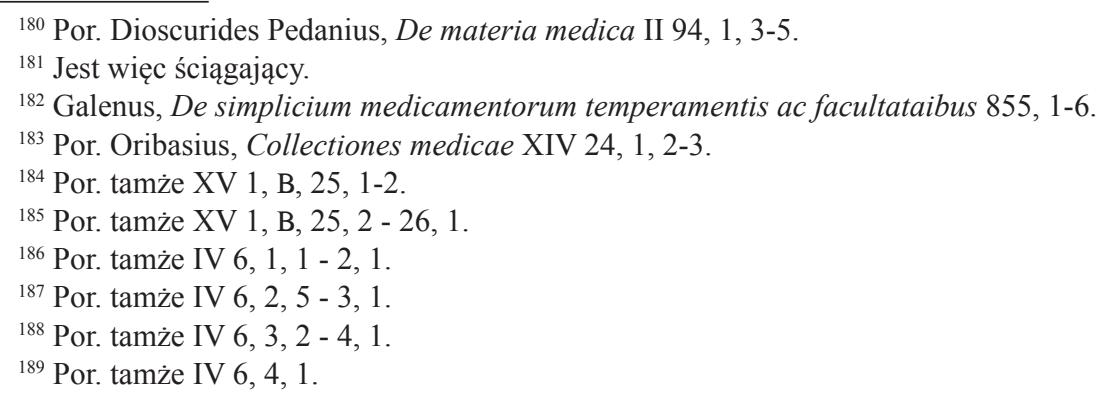


owe rzadkie wywary - jak pisaliśmy poprzednio - miały swoje zastosowanie $\mathrm{w}$ sporządzaniu enem odpowiednich do leczenia chorych na dyzenterię ${ }^{190}$.

Aecjusz $\mathrm{z}$ Amidy pozostał $\mathrm{w}$ sferze analogicznych doktryn. W jego Iatricorum libri czytamy bowiem o ściągających właściwościach owsa i zastosowaniu go jako lekarstwa przeciw biegunkom, o czym pisał już Galen ${ }^{191}$. Nadto, podobnie jak Orybazjusz, wspomniał Amideńczyk, o delikatnym dla tkanek, wysuszającym działaniu omawianego zboża ${ }^{122}$. Należy zatem rozumieć, że lekarz ten myślał o zastosowaniu owsa w diaforetycznych okładach, które były już wymieniane przy analizie doktryn jego poprzedników.

Stosunkowo wiele informacji na temat procedur medycznych, w których wykorzystywano właściwości owsa, przekazał nam Aleksander z Tralles. Owies wymieniony jest więc we fragmencie Therapeutica, poświęconym wykorzystaniu ő $\sigma \pi \rho \imath \alpha$. Te produkty właśnie, jak utrzymywał autor, są przydatne jako pożywienie w kuracjach chorób, którym towarzyszy wysoka temperatura. W czasie trwania tego stanu, jak pisał rzeczony medyk, podawano pacjentom $\pi \tau \imath \sigma \alpha ́ v \eta ~ l u b ~ o w i e{ }^{193}$. Informację tę interpretujemy jako nawiązanie do serwowania gorączkującym zupy analogicznej do $\pi \tau \imath \sigma \alpha ́ v \eta$, ale ugotowanej na bazie owsa. Autor ciągnął swój wykład relacjonując, że - gdy gorączka się obniży i nie trawi już tak organizmu chorego - przechodzono do podawania pacjen-

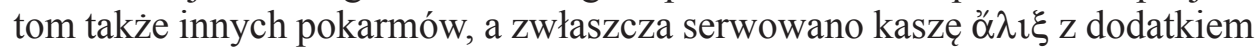
pistacji, migdałów, rodzynek lub orzeszków piniowych. Dodawał również, że gdy pacjent gorączkował wskutek jątrzenia się rany lub owrzodzenia ( dawano mu bób, fasolę (Vigna sinensis) lub zupę z soczewicy, czyli $\varphi \alpha \kappa \hat{\eta ̂}$ (tę ostatnią albo bez dodatków albo też gotowaną wraz z $\pi \tau \imath \sigma \alpha ́ v \eta)$. Gotowany owies musiał być uważany jednak za pokarm o szczególnie dobroczynnych właściwościach, gdyż medyk twierdził także, że wszystkie wyżej wymienio-

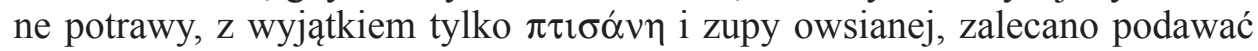
dopiero, gdy szczyt dolegliwości gorączkowej już przeminą ${ }^{194}$. Nadto z De

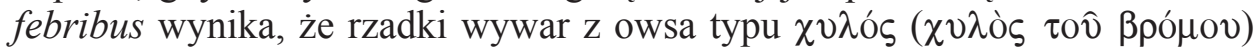
podawano jako pokarm osobom cierpiącym na gorączkę trzydniową ${ }^{195}$.

Po drugie, Aleksander przewidywał zastosowanie kleików z owsa w leczeniu dolegliwości układu pokarmowego. Ich rozcieńczona a więc rzadka wersja ${ }^{196}$ podawana była jako zasadnicza część pożywienia cierpiącym na bóle brzucha spowodowane zapaleniem przewodu pokarmowego ( $\dot{\varepsilon} \pi \dot{\imath} \varphi \lambda \varepsilon \gamma \mu o v \hat{n}$

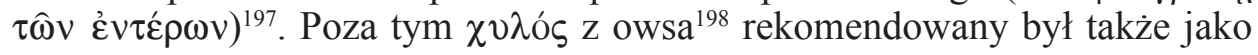

\footnotetext{
${ }^{190}$ Lekarze wykorzystywali w tym przypadku również właściwości ściągające tego zboża.

${ }^{191}$ Por. Aetius Amidinus, Iatricorum lib. I 73, 1-2.

192 Por. tamże II 208, 2.

${ }^{193}$ Por. Alexander Trallianus, Therapeutica II 221, 15.

${ }^{194}$ Por. tamże II 221, 13-20.

${ }^{195}$ Por. tenże, De febribus I 371, 9-10.

${ }^{196}$ Por. tenże, Therapeutica II 373, 13-14.

${ }^{197}$ Por. tamże II 371, 26 - 373, 31.

${ }^{198}$ Por. tamże II 383, 1-3.
} 


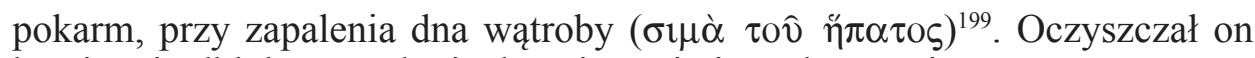
bowiem i odblokowywał, nie drażniąc ani nie podgrzewając tego organu.

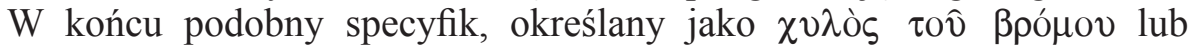
$\dot{\alpha} \pi$ ó $\varepsilon \mu \alpha$ był używany jako lek ułatwiający odkrztuszanie flegmy ${ }^{200}$. Także i ta doktryna ma swoje uzasadnienie w zaprezentowanych już ustaleniach wcześniejszych medyków.

Paweł z Eginy nie zawarł w swej pracy wielu informacji, które bezpośrednio mówiłyby o terapeutycznych zastosowaniach owsa. W księdze VII Epitome ${ }^{201}$ wspomniał jednak o umiarkowanych właściwościach wysuszających owsa oraz o wydaleniu za jego przyczyną produktów przemiany materii bez uszkadzania tkanek ${ }^{202}$. Sądzimy więc, że zalecał stosowanie owsa w kataplazmach, o których działaniu była już mowa. Dodatkowo w tym samym fragmencie, idąc również za doktrynami poprzedników, stwierdził, że owies używany jest jako środek przy leczeniu biegunek z racji na swoje właściwości ściągające ${ }^{203}$.

Nadto Egineta zachował także istotną informację o przyrządzaniu leczniczej zupy z owsa, która była odpowiednikiem $\pi \tau i \sigma o ́ v \nu \eta^{204}$. Prawdopodobnie tym samym postulował on jej zastosowanie w przypadkach, gdy organizm wymagał oczyszczenia, schłodzenia i nawodnienia, czyli w sytuacjach, gdy zazwyczaj podawano chorym tego rodzaju zupę. Zgodnie z przytoczonymi już wcześniej informacjami pokarm ten mógł być podawany, na przykład, w stanach gorączkowych.

Wreszcie ten sam lekarz przewidywał owies w żywieniu osób wychodzą-

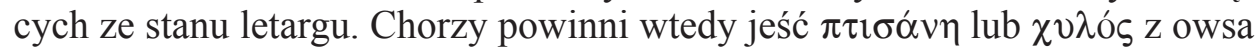
(zapewne chodzi o rzadką zupę), albo $\chi 0 \lambda o ́ \varsigma z$ ö $\lambda \iota \xi$ doprawiany ỏ $\xi u ́ \mu \varepsilon \lambda \imath$ lub solą, albo też miętą polną 205 .

Przedstawione powyżej rozważania, oparte głównie na danych medycznych, doprowadzają nas do wniosku, iż owies towarzyszył człowiekowi nieprzerwanie przez cały omawiany przez nas okres, to znaczy pomiędzy $\mathrm{V}$ w. przed Chr. a XI w. po Chr. Ze świadectw można wnioskować, iż w basenie Morza Śródziemnego traktowany był jako chwast w uprawach pszenicy lub jęczmienia i nie był zbożem popularnym ani cenionym. Gdy na północ od Alp oraz Dunaju spożywany był jako składnik codziennej diety już w okresie sta-

${ }^{199}$ Por. tamże II 381, 4 - 385, 2.

${ }^{200}$ Fragment poświęcony wywarom, gdzie znajdujemy te informacje, zawarł w swym dziele Aleksander z Tralles (Therapeutica II 241, 13 - 243, 5).

${ }^{201}$ Por. Paulus Aegineta, Epitomae medicae lib. VII 3, 2, 77-79.

${ }^{202}$ Por. tamże VII 3, 2, 77.

${ }^{203}$ Por. tamże VII 3, 2, 78-79.

${ }^{204}$ Por. tamże I 78, 24-25.

${ }^{205}$ Por. tamże III 9, 3, 31-32. 
rożytności, mieszkańcy południowej Europy i Azji Mniejszej (o których obyczajach żywieniowych mówią właśnie źródła medyczne) traktowali go jako pożywienie odpowiednie dla ludzi (średniozamożnych i dostatnio żyjących) tylko w czasach głodu (tzn. w czasie braku wystarczających ilości pszenicy i jęczmienia) oraz jako paszę dla zwierząt gospodarskich.

$\mathrm{Z}$ jednej strony nieprzychylna opinia towarzysząca owsu w społeczeństwach śródziemnomorskich związana była $z$ utrwaloną opinią o nieprzyjemnym (w porównaniu z wymienionymi dwoma głównymi zbożami) smaku pieczonego z niego chleba i gotowanej z owsa zupy-papki typu $\pi$ ó $\lambda \tau$ ○ร, oraz przeświadczeniem, że inne popularne zboża są dietetycznie mu równe albo nawet lepsze. To właśnie zdanie wyrażali kolejno po sobie następujący lekarze piszący na przestrzeni niemal półtora tysiąca lat: Hipokrates, Dioskurides, Galen, Orybazjusz, Aecjusz z Amidy, Aleksander z Tralles, Paweł z Eginy, Symeon Seth oraz cytowani w niniejszym studium autorzy anonimowi.

$\mathrm{Z}$ drugiej jednak strony, wymienione autorytety opisywały również sytuacje, w których można było, a nawet należało zastosować owies dla poprawy stanu zdrowia. Główne właściwości terapeutyczne tego zboża i uzyskiwanych z niego produktów polegały na spowalnianiu pracy układu pokarmowego (co było krytycznie ważne przy leczeniu biegunek), dalej na działaniu przez skórę, a więc sprzyjaniu diaforezie, i na zdolności do oczyszczania dróg oddechowych z zalegającej w nich flegmy, gdy używano owsa do produkcji rzadkich kleików.

Wypada dodać, iż pozycji swej nie udało się owsowi wzmocnić nie tylko do końca XI w., który wyznacza umowną granicę naszych rozważań, ale i na długo potem. Dopiero wiek XX i przeprowadzone wówczas specjalistyczne badania właściwości dietetycznych owsa spowodowały, że zaczął on być bardziej powszechnie doceniany jako wartościowy i prozdrowotny produkt spożywczy. Pomimo to, wciąż zaledwie kilka procent $\mathrm{z}$ jego stale spadających plonów wykorzystuje się w formie pożywienia dla ludzi ${ }^{206}$.

\section{THE COMMON OAT IN GREEK MEDICAL TREATISES OF ANTIQUITY AND BYZANTIUM $\left(\mathrm{V}^{\mathrm{TH}} \mathrm{C}\right.$. BC - XI ${ }^{\mathrm{TH}} \mathrm{C}$. AD)}

\section{(Summary)}

The common oat (Avena sativa) is a kind of cereal which is fairly well attested in the ancient and Byzantine Greek sources. It is to be noted that medical literature of the abovementioned periods is especially informative as far as the subject in question is concerned. The body of evidence shows that both in Antiquity as well as over the Byzantine period (i.e. between the $\mathrm{V}^{\text {th }}$ and the $\mathrm{XI}^{\text {th }}$ centuries) oats

${ }^{206} \mathrm{Na}$ temat tendencji dotyczących owsa we współczesnym rolnictwie i gastronomii por. Górny, Zarys genetyki owsa, s. 313-314; A. Kawka, Wspótczesne trendy w produkcji piekarskiej-wykorzystanie owsa i jęczmienia jako zbóż niechlebowych, „Żywność. Nauka. Technologia. Jakość” (2010) nr 3 (70), 25-43. 
belonged to the crops which did not enjoy much appreciation nor special attention on the part of both mass consumers as well as medical specialists. Generally the cereal was thought to be worse than other crops and therefore lending itself to being animal fodder. It was made use of almost exclusively as an emergency food in case of shortages of other cereals.

Though there are very few recipes that refer directly to the ways of preparing oats as food, some guidelines can be formulated on the basis of information pertaining to other cereals. The analyzed sources appear to suggest that it was used to prepare thin soups (on the basis of oats cooking liquor) termed $\alpha \pi \delta ́ \zeta \varepsilon \mu \alpha, \chi \nu \lambda o ́ s$,

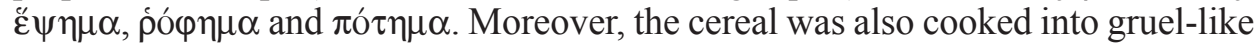
soups called $\pi$ o $\lambda \tau$ ós. Having been finely ground, it could also be utilized to prepare bread, which, however, was not highly appreciated for its taste nor dietetic value.

Medical sources characterize oats in reasonable detail. The cereal is said to be not very appealing in its flavour (which reveals unbalanced humours), characteristic of limited wholesomeness, slightly astringent (and therefore slowing down the work of the alimentary tract), hard to digest, delicately desiccating, heating and cooling at the same time.

The same material suggests that oats were used for therapeutic purposes. Mainly they were profited from to treat diarrhea, stomach problems, liver ailments, prepare cataplasms to stimulate diaphoresis, help remove mucus from the bronchi and feed the feverish.

Slowa kluczowe: antyczna i bizantyńska medycyna, antyczna i bizantyńska dietetyka, antyczna i bizantyńska gastronomia, historia uprawy owsa.

Key words: ancient and Byzantine medicine, ancient and Byzantine dietetics, ancient and Byzantine gastronomy, history of oats cultivation. 
